\title{
Paper Birch Decline in the Niobrara River Valley, Nebraska: Weather, Microclimate, and Birch Stand Conditions
}

Open-File Report 2009-1221

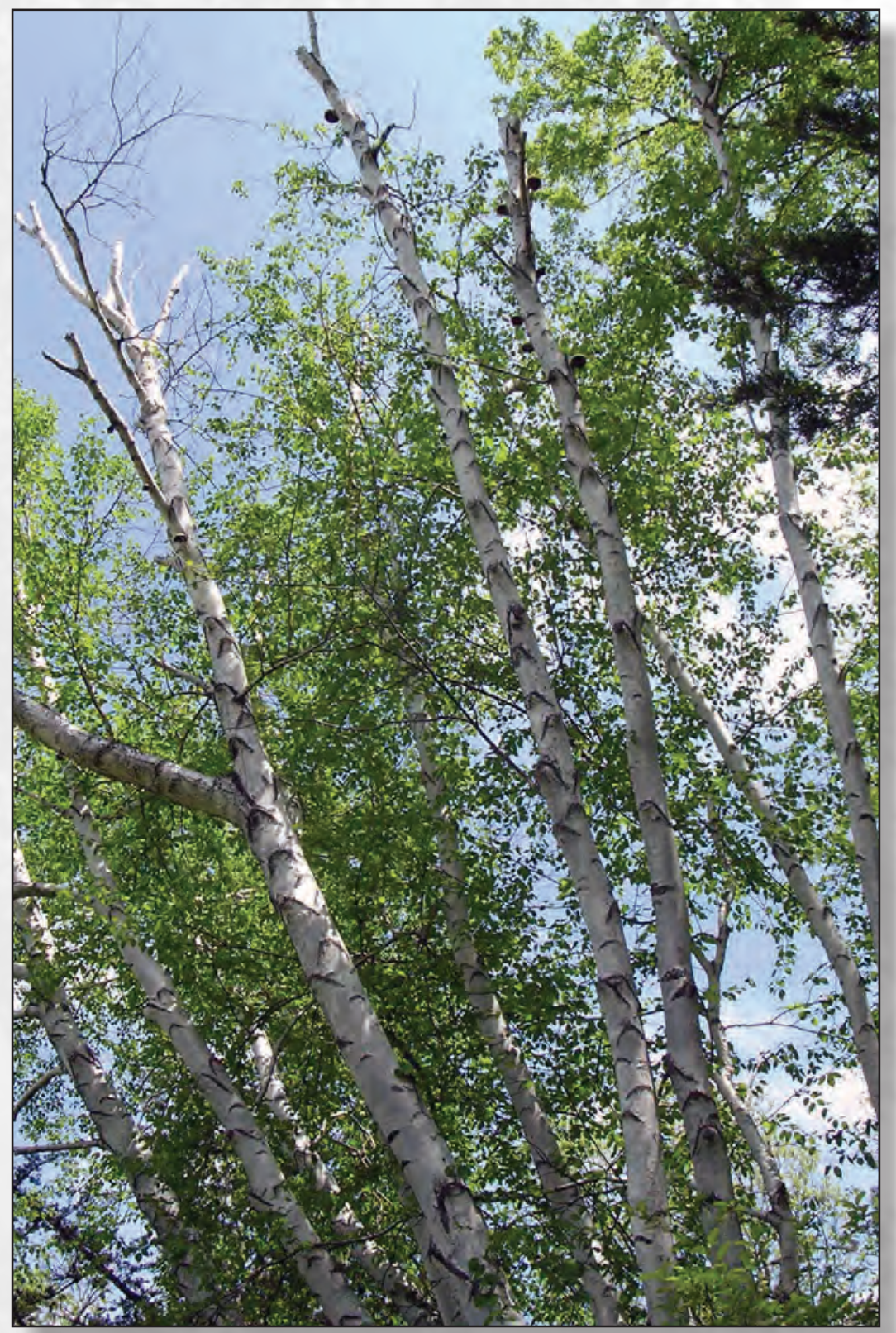

U.S. Department of the Interior

U.S. Geological Survey 
Cover photograph. Paper birch (Betula papyrifera) tree with over over one-half of its canopy dead. Mature birch trees in remnant populations in the Niobrara River Valley are exhibiting extensive canopy dieback. Frequency of spring freeze/thaw conditions capable of inducing rootlet injury and subsequent crown dieback have significantly increased from 1978-2007 as compared to 1948-1977. Photo taken along the Niobrara River, Nebraska, near Rocky Ford, May 2006. 


\section{Paper Birch Decline in the Niobrara River Valley, Nebraska: Weather, Microclimate, and Birch Stand Conditions}

By Esther D. Stroh and Joel P. Miller

Open-File Report 2009-1221 


\title{
U.S. Department of the Interior \\ KEN SALAZAR, Secretary
}

\section{U.S. Geological Survey Suzette M. Kimball, Acting Director}

\author{
U.S. Geological Survey, Reston, Virginia: 2009 \\ Revised and reprinted: 2009
}

\author{
For more information on the USGS — the Federal source for science about the Earth, its natural and living resources, \\ natural hazards, and the environment, visit http://www.usgs.gov or call 1-888-ASK-USGS \\ For an overview of USGS information products, including maps, imagery, and publications, \\ visit http://www.usgs.gov/pubprod \\ To order this and other USGS information products, visit http://store.usgs.gov
}

\begin{abstract}
Any use of trade, product, or firm names is for descriptive purposes only and does not imply endorsement by the U.S. Government.

Although this report is in the public domain, permission must be secured from the individual copyright owners to reproduce any copyrighted materials contained within this report.
\end{abstract}

Suggested citation:

Stroh, E.D., and Miller J.P., 2009, Paper birch decline in the Niobrara River Valley, Nebraska: weather, microclimate, and birch stand conditions: U.S. Geological Survey Open-file Report 2009-1221, 19 p. 


\section{Contents}

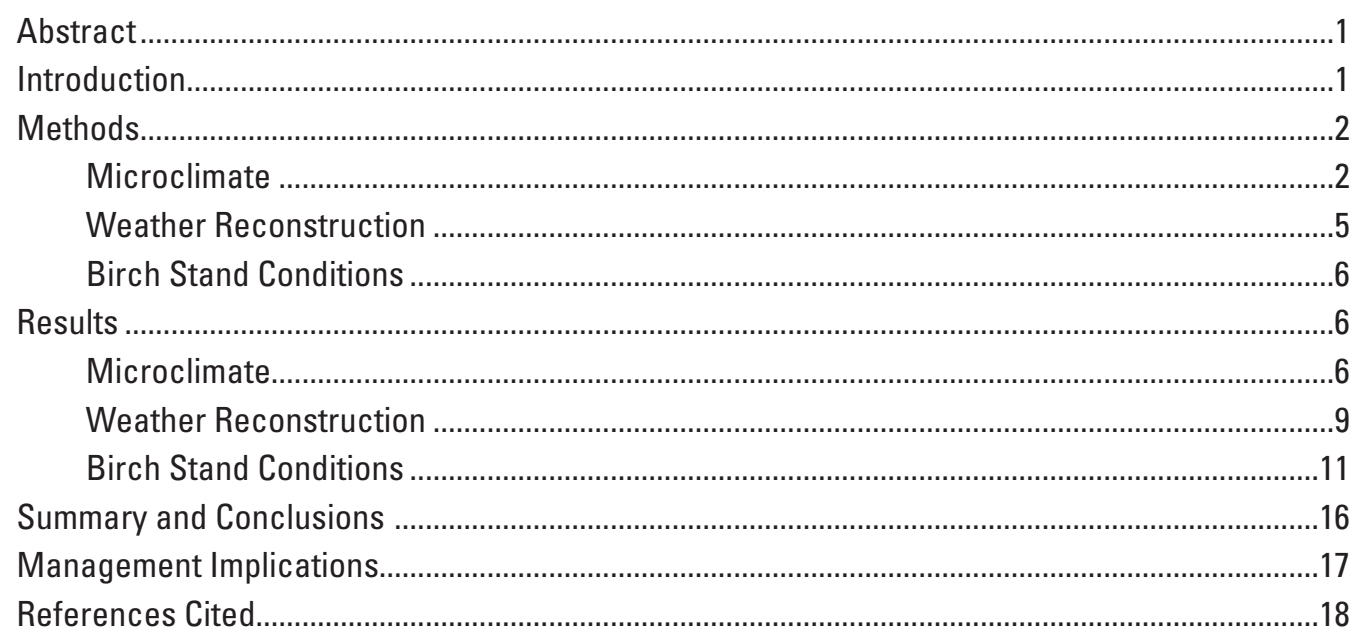

\section{Figures}

\section{1-2. Maps showing-}

1. Site locations in the west (upper) part of the Niobrara River study area ....................

2. Site locations on the east (lower) part of the Niobrara River study area....................

3-11. Graphs showing-

3. Ninety-five percent confidence intervals for four microclimate temperature parameters in Niobrara Valley birch stands for comparison by site type or site location and at two weather stations, March through May 2006.

4. Ninety-five percent confidence intervals for four temperature parameters in Niobrara Valley birch stands for comparison by site type or site location and at two weather stations, June through August 2006

5. Observed diurnal temperature variation for weather stations.................................12

6. Observed winter diurnal temperature variation for one weather station and one data logger

7. Observed spring diurnal temperature variation for one weather station and one data logger

8. Observed summer diurnal temperature variation for one weather station and one data logger

9. Observed fall diurnal temperature variation for one weather station and one data logger.

10. Average decadal absolute value difference between smoothing estimates for one weather station and one data logger for $A$, minimum temperature and $\mathrm{B}$, maximum temperature

11. Relations between percentage living trees in 12 birch stands to environmental distance of site minimum temperature from The Nature Conservancy site minimum temperature, January 1 through December 31, 2006 


\section{Tables}

1. Site, ownership, map code, site type, and river location for birch study sites in the Niobrara Valley.

2. Mean values and 95 percent confidence intervals for temperature variables in 12 birch stands and at 2 weather stations in the Niobrara River Valley, Nebraska, from January 1, 2006, through December 31, 2006

3. Environmental distance in degrees Celsius between microclimate in 12 birch stands and a reference weather station in the Niobrara River Valley, Nebraska, for 3 temperature parameters from January 1, 2006, through December 31, 2006...........8

4. March growing degree days and lowest April and May daily minimum temperature in 12 birch stands and at 2 weather stations in the Niobrara River Valley for 2006 and 2007

5. March Growing Degree Days and lowest May minimum temperature at Valentine Miller Field from 1948 to 2007.

6. Mean differences between each of three weather station pairs for periods where they shared data $(4 / 13 / 05$ to $10 / 31 / 07)$ and where only modeled smoothing estimates are available (1/1/50 to $4 / 12 / 05)$

7. Size, basal area, and birch health conditions in 25 paper birch stands in the Niobrara Valley, Nebraska, in 2006 (Year 1) and 2007 (Year 2) 


\section{Conversion Factors}

\begin{tabular}{|c|c|c|}
\hline Multiply & By & To obtain \\
\hline \multicolumn{3}{|c|}{ Length } \\
\hline centimeter $(\mathrm{cm})$ & 0.3937 & inch (in.) \\
\hline meter $(\mathrm{m})$ & 3.281 & foot $(\mathrm{ft})$ \\
\hline kilometer (km) & 0.6214 & mile (mi) \\
\hline \multicolumn{3}{|c|}{ Area } \\
\hline hectare (ha) & 2.471 & acre \\
\hline \multicolumn{3}{|c|}{ Density } \\
\hline square meter per hectare $\left(\mathrm{m}^{2} / \mathrm{ha}\right)$ & 4.355 & square foot per acre $\left(\mathrm{ft}^{2} /\right.$ acre $)$ \\
\hline
\end{tabular}

Temperature in degrees Celsius $\left({ }^{\circ} \mathrm{C}\right)$ may be converted to degrees Fahrenheit $\left({ }^{\circ} \mathrm{F}\right)$ as follows:

${ }^{\circ} \mathrm{F}=\left(1.8 \times{ }^{\circ} \mathrm{C}\right)+32$ 



\title{
Paper Birch Decline in the Niobrara River Valley, Nebraska: Weather, Microclimate, and Birch Stand Conditions
}

\author{
By Esther D. Stroh and Joel P. Miller
}

\section{Abstract}

The Niobrara River Valley in north-central Nebraska supports scattered stands of paper birch (Betula papyrifera Marsh), a species more typical of boreal forests. These birch stands are considered to be relictual populations that have persisted since the end of the Wisconsin glaciation, when regional flora was more boreal in nature (Wright 1970, Kaul and others, 1988). Dieback of canopy-sized birch has been observed throughout the Niobrara Valley in recent years, although no onset dates are documented. The current dieback event probably started around or after the early 1980's. The study objectives were to understand microclimatic conditions in birch stands relative to nearby weather stations and historic weather conditions, and to assess current health conditions of individual birch trees. Temperature was measured every halfhour from June 2005 through October 2007 in 12 birch stands and individual birch tree health was measured as expressed by percent living canopy in these and 13 additional stands in spring 2006 and 2007. Birch site microclimate was compared to data from a National Weather Service station in Valentine, Nebraska, and to an automated weather station at The Nature Conservancy Niobrara Valley Preserve 24 kilometers north of Johnstown, Nebraska. Historic weather data from the Valentine station and another National Weather Service Station at Ainsworth, Nebraska, were used to reconstruct minimum and maximum temperature at The Nature Conservancy and one microclimate monitoring station using Kalman filtering and smoothing algorithms. Birch stand microclimate differed from local weather stations as well as among stands. Birch health was associated with annual minimum temperature regimes; those stands whose annual daily minimum temperature regimes were most like The Nature Conservancy station contained smaller proportions of living trees. Frequency of freeze/thaw conditions capable of inducing rootlet injury and subsequent crown dieback significantly have increased in the second one-half of the period of record (1978-2007) as compared to the first one-half (1948-1977). River location was associated with birch health; upper river sites had significantly healthier trees than north bank sites. Localized microclimates in the birch stands have likely facilitated the persistence of the birch populations in a region otherwise unsuitable for the species. These microclimate differences may reduce frequency of thaw/freeze conditions that can induce root injury and potential crown dieback. A large population decline in the context of increased frequency of potentially injurious climatic events would make population recovery much more difficult now than from 1948 to 1977, when thaw/freeze conditions were less frequent. These conditions, combined with little evidence of recruitment of young birch and great geographic distances from potential immigrant sources, make the future persistence of birch in the Niobrara River Valley stands uncertain.

\section{Introduction}

The Niobrara River Valley in north-central Nebraska supports a considerable diversity of species that are rarely found in close proximity to each other. In this Great Plains valley, species representing three prairie types (sandhills, mixedgrass, and tallgrass) and three forest types (western coniferous, eastern deciduous, and boreal) can be found in a patchwork of rolling hills and steep valley slopes. Some species are at or beyond their typical geographic limit, including paper birch (Betula papyrifera Marsh), the primary representative of the boreal forest component in the Niobrara River Valley. More than 30 sites with paper birch are scattered along approximately 80 kilometers $(\mathrm{km})$ of the Niobrara River, immediately east of Valentine. This location is $400 \mathrm{~km}$ southwest of central Minnesota, the edge of the primary range for paper birch. The Niobrara River Valley birch are considered to be relictual populations that have persisted since the end of the Wisconsin glaciation, when regional flora was more boreal in nature (Wright 1970; Kaul and others, 1988). Resource managers with the National Park Service (NPS), the U.S. Fish and Wildlife Service (FWS), and The Nature Conservancy (TNC) have observed dieback of canopy-sized birch throughout the Niobrara Valley in recent years, although no onset dates are documented. The current dieback event probably started around or after the early 1980 's. Notes from a 1982 inventory 
of birch stands in the Niobrara Valley do not mention dieback of birch trees and lists only erosion and grazing as threats to stand viability (S.P. Churchill and C.C. Freeman, The Nature Conservancy Niobrara Valley Preserve, written commun., 1982). Although a few boreal ferns, shrubs, forbs, and club mosses also occur in the region, NPS pamphlets feature the paper birch as a primary visitor attraction. Loss of the paper birch would substantially alter the natural characteristics of the Niobrara National Scenic River and eliminate the principal component of one of the six ecosystem types represented in the Niobrara Valley.

Crown dieback begins in the upper crown at the tips of fine twigs and proceeds inward toward the trunk. "Dead branches in the lower portion of the live crown are assumed to have died from competition and shading. Dead branches in the lower live crown are not considered as part of crown dieback, unless there is continuous dieback from the upper and outer crown down to those branches" (U.S. Department of Agriculture, 2005). Paper birch experienced widespread dieback in other areas. For example, from 1935 through the mid-1940's, dieback of birch trees was observed in Nova Scotia, Canada, and Maine, killing 67 percent of paper birch and yellow birch (Betula alleghaniensis Britt) in Maine and leaving 15 percent of remaining birch in a dying condition (Nash and Duda, 1951). Although no clear reason for this dieback was discerned, likely causes included low winter temperatures, late spring freezes, unfavorable combinations of precipitation and temperature, or other climatic abnormalities (Nash and Duda, 1951; Greenidge, 1953; Braathe, 1995). Although a root fungus [Armillaria mellea (Vahl: Fr.) Kummer] and the bronze birch borer (Agrilus anxius Gory) were associated with healthy and dying birch, neither was indicated as the primary cause of the widespread dieback (Nash and Duda, 1951). Birch dieback in eastern and upper Midwestern forests has been associated with infection by the silver-leaf fungus Chondrostereum purpureum (Setliff, 2002), with cold winter temperatures and minimal snow cover (Pomerleau, 1991), and with early spring thaws followed by hard frosts (Braathe, 1995; Auclair and others,1996; Cox and Malcolm, 1997; Bourque and others, 2005). Birch dieback episodes occurred in eastern forests from 1976 through 1995, in Appalachian forests in 1983 through 1989, and in midwestern forests in 1954 through 1963, and 1977 through 1993; dieback episodes observed in other tree species have been attributed to cyclic and predictable long-term population dynamics (Auclair, 2005).

Crown dieback in birch can be triggered by and is an expression of rootlet mortality (Greenidge, 1953; Redmond, 1955; Braathe, 1995). Increasing summer soil temperatures by 1 and 2 degrees Celsius increases rootlet mortality in mature yellow birch by 13 and 54 percent (Redmond, 1955), and shallow birch roots can be injured by thawing and then refreezing (Pomerleau, 1991). Damaged birch roots are less able provide sufficient root pressure to refill the stem xylem with sap in the spring (Cox and Malcolm, 1997; Zhu and others, 2000). An early spring thaw/freeze cycle consisting of March growing degree days (GDD) totaling greater than 50 followed by April or May temperatures below $-4{ }^{\circ} \mathrm{C}$ is sufficient to induce root injury and subsequent crown dieback in paper birch (Braathe, 1995; Bourque and others, 2005).

Climate is one of the main factors governing the geographical distribution of marginal tree populations (Woodward, 1987). Paper birch is a cold climate species and rarely occurs naturally where average July temperatures exceed $21^{\circ} \mathrm{C}$ (U.S. Department of Agriculture, 1965). The average July temperature in Valentine, $4 \mathrm{~km}$ from the westernmost Niobrara Valley birch stand, is $23^{\circ} \mathrm{C}$ (National Weather Service, 2008). However, sites with suitable microclimates, for example, cool north-facing locations, can support relict populations of prehistoric flora for thousands of years far from the primary range of the species (Stebbins and Major, 1965; Billings and Anderson, 1966).

Along the Niobrara River, birches occur in three types of sites: narrow, north-facing canyons (canyon sites); steep, north-facing banks along the river edge (riverfront sites); and a few small canyons on the north side of the river (north canyon sites). Canyon and riverfront sites have northern exposures and occur on the south side of the Niobrara River. Canyon sites are approximately V-shaped, with the open end located from 10 to more than $300 \mathrm{~m}$ (meters) from the river; riverfront sites are linear and located on the edge of the river, often at the edge of steep cliffs. North canyon sites typically are in protected small canyons that can have a variety of exposures.

The study hypotheses were 1) Niobrara Valley sites with birch populations maintain microclimates that differ from the regional climate measured at a nearby National Weather Service (NWS) station at Valentine Miller Field (VMF) in Valentine, and 2) birch sites differ in their microclimates according to their location along the river (upper, lower or north bank) or their site type (canyon, riverfront, or north bank). The objectives of the study were to assess individual tree condition within stands; investigate associations between birch stand health and differences in stand type, location, and microclimate parameters; construct a model of historic Niobrara Valley weather; and understand the relation between birch stand microclimate and regional weather and climate. The purpose of this report is to present the study results and management implications for the Niobrara Valley birch populations.

Study sites consisted of 25 birch stands located within the Niobrara River Valley (figs. 1, 2). They represented a mix of stand type (canyon, riverfront, north canyon), location (upper or lower river), ownership, and study use (table 1).

\section{Methods}

\section{Microclimate}

Site location data from a survey of 46 birch stands (S.P. Churchill and C.C. Freeman, The Nature Conservancy Niobrara Valley Preserve, written commun., 1982) was used 


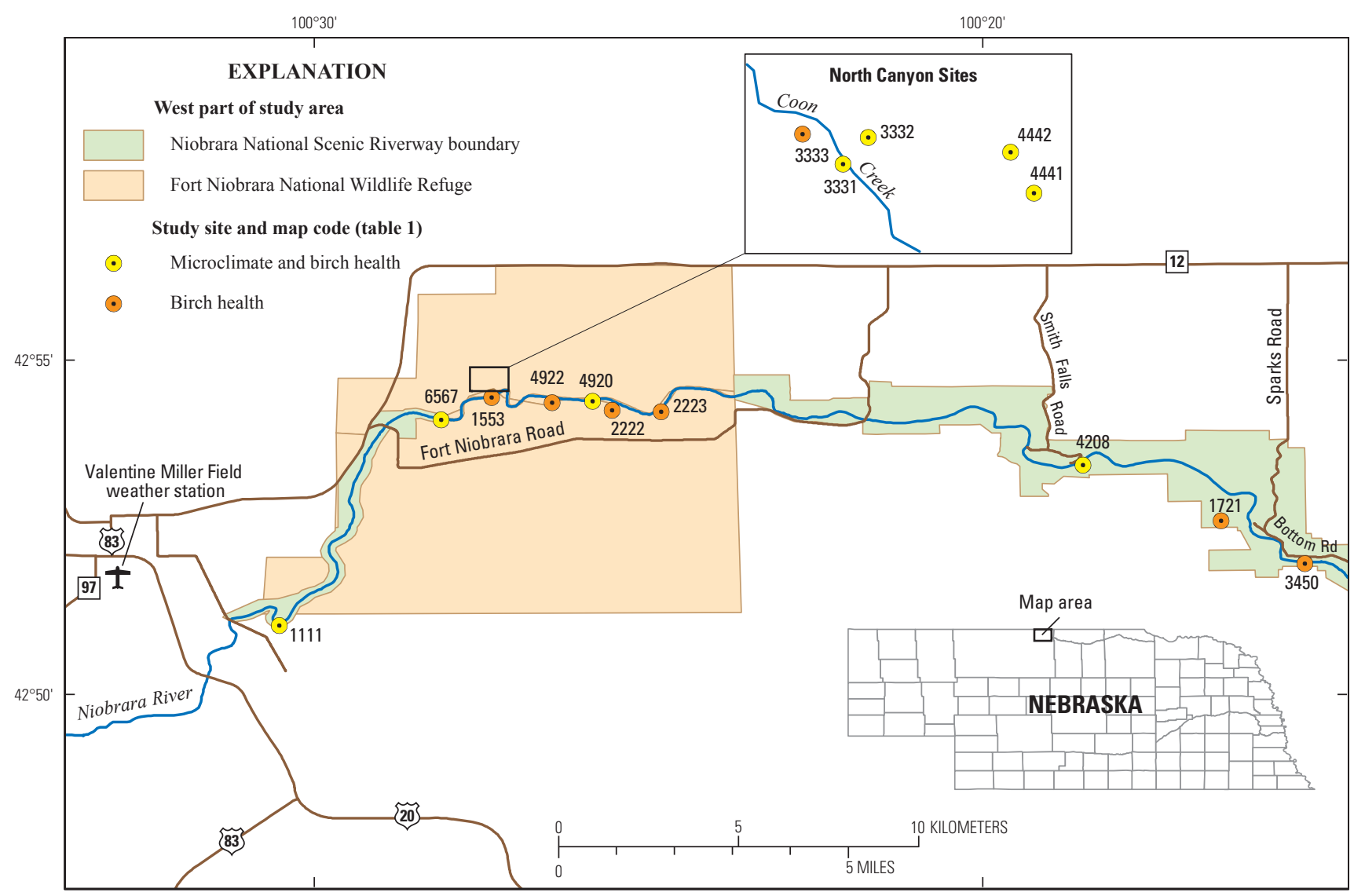

Base from U.S. Geological Survey digital data 1:100,000 1990 Universe Transverse Mercator projection, Zone 14

Figure 1. Site locations in the west (upper) part of the Niobrara River study area.

to select 12 sites representing the full extent of surveyed birch stands for microclimate monitoring. Sites representing three river locations were selected: four upper river sites (sites 111, 6567, 4920, and 4208; approximately from river mile 0 to 20; fig. 1, table 1), four lower river sites $(6420,1803,5074$, and 6581; approximately from river mile 26 to 42 ; fig. 2, table 1 ), and four of the much less common north bank sites (3331, 3332 , 4442, and 4441; fig. 1, table 1). The sites also represented the three types of birch stands: canyon and riverfront sites along the south bank and small north canyon sites. In May and June 2005, two Hobo Pro RH/Temp data loggers (Onset Computer Corporation) were placed in each microclimate monitoring site. Data loggers were positioned to capture a range of conditions in each site type. In canyon sites, one monitor was positioned randomly on the west facing canyon slope and one randomly on the east facing canyon slope. In the narrow, linear riverfront sites, one monitor was positioned near the uppermost (western) birch tree in the stand and the other was positioned near the lowermost (eastern) birch tree in the stand. One data logger was placed in each of the smaller north canyon sites near a randomly selected birch tree. Each data logger was mounted inside a translucent white plastic box to protect from direct sunlight and rainfall; the boxes were open at the bottom for ventilation. The boxes were tied to the boles of small trees, usually Ostrya virginiana (American hophornbean), using nylon cord. Data loggers were programmed to take temperature and humidity measurements on the hour and half-hour beginning in mid-June 2005. Data were downloaded in October 2005, May or June 2006 and 2007, October 2006, and November 2007.

In April 2005, a Campbell automatic weather station Model CM10 (Campbell Scientific, Inc., Logan, Utah) was installed at TNC Niobrara Valley Preserve office compound (fig. 2). The automated weather station is located within the river valley near the easternmost birch populations and closer to the river than the weather station at VMF (fig. 1). The VMF station is near but not in the river valley. The TNC weather station data were used as a reference for weather conditions within lower part of the river valley study area in a location where birches are absent. The station data are refreshed every 5 minutes and are available at $h t t p: / / a g e b b . m i s s o u r i . e d u /$ weather/realtime/niobrara.asp.

Daily minimum, maximum, and mean temperature data were obtained from the VMF weather station for the period of record, 1948 to 2007 (National Climatic Data Center, 2005-2007). For microclimate monitoring site and TNC weather station data, daily temperature means were calculated using all values on a given date. Diurnal temperature range 


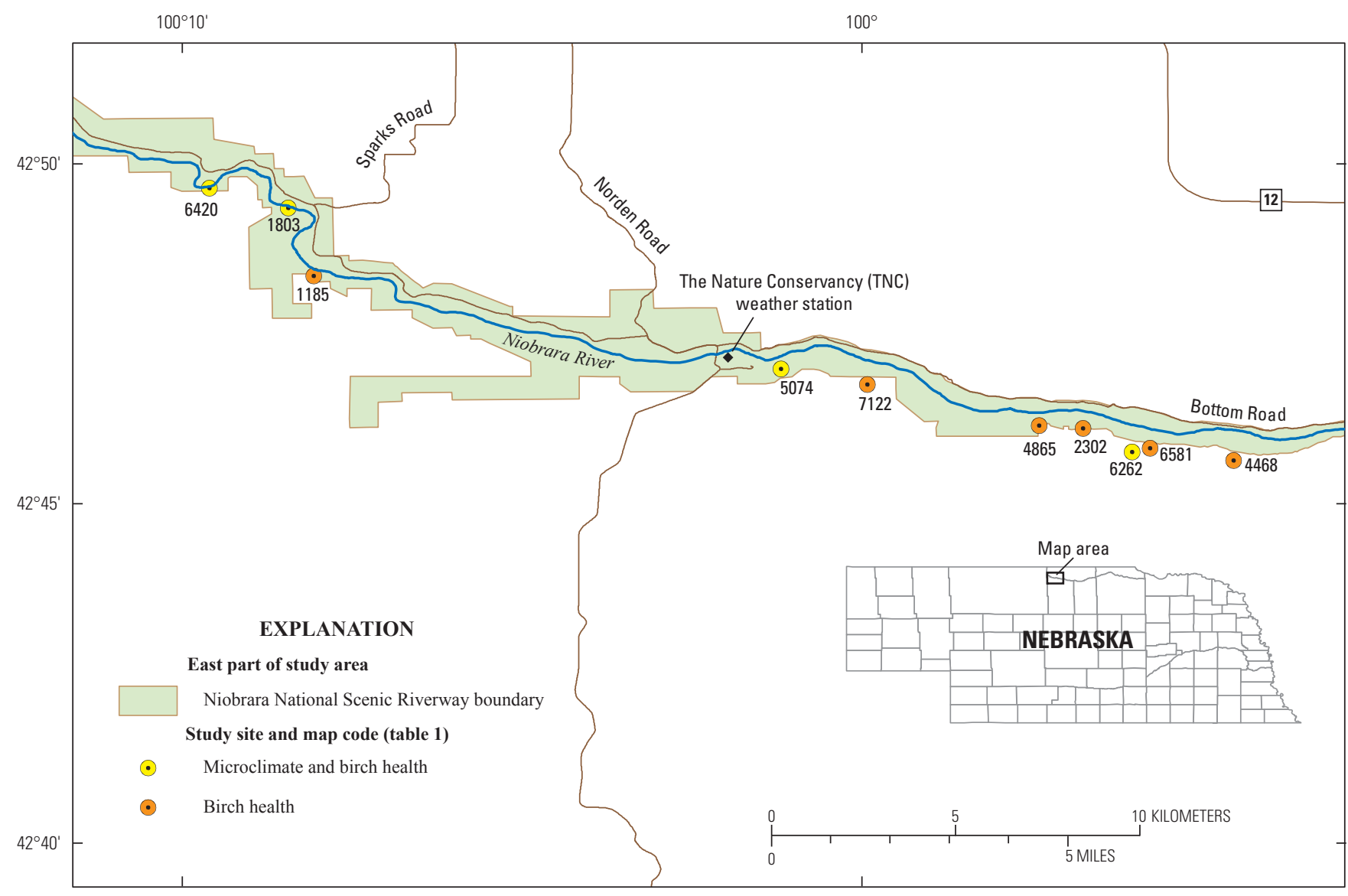

Base from U.S. Geological Survey digital data 1:100,000 1990

Universe Transverse Mercator projection, Zone 14

Figure 2. Site locations on the east (lower) part of the Niobrara River study area.

was calculated as the difference between the maximum and minimum recorded values on a given date. For canyon and riverfront sites, daily mean values were then averaged between the two data loggers.

To test for site and location differences, birch sites were partitioned by location (upper river, lower river, north bank) and type (canyon, riverfront, north canyon). Temperature data were partitioned into three-month seasonal blocks (December, January, February; March, April, May; June, July, August; and September, October, November) according to protocols used by the Intergovernmental Panel on Climate Change for regional climate summaries (Christensen and others, 2007). The 95 percent CI (confidence intervals) for these time periods in 2005, 2006, and 2007 were calculated for daily mean, minimum, and maximum temperature, and diurnal temperature range for the twelve microclimate sites, the TNC automated weather station, and VMF (Systat Software, Inc., 2004).

Various microclimate parameters were hypothesized to vary among individual birch sites. To quantify the degree to which microclimate in birch sites differed individually from conditions in sites without birch, a metric of environmental distance (ED) was calculated between each birch microclimate monitoring site and the TNC weather station for daily minimum temperature, daily maximum temperature, and diurnal temperature range. The ED has been used to compare microclimatic conditions between study and reference sites (Sanders and McGraw, 2005) and is calculated as:

$$
E D_{j}=\sum_{i=12 / 31 / 2006}^{1 / 1 / 2006} \sqrt{\left(E_{i, j}-E_{i, T N C}\right)^{2}}
$$

where

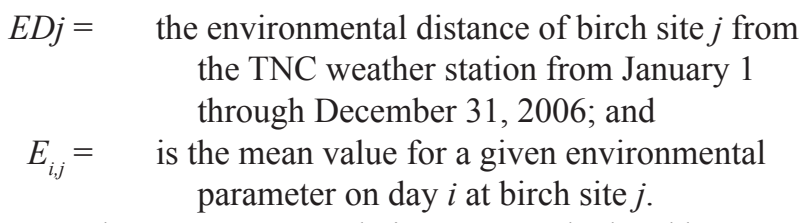

Pearson product-moment correlations were calculated between environmental distance and mean, minimum, and maximum temperature and diurnal range (Systat Software, Inc., 2004).

The GDD were calculated to estimate spring thaw conditions using March 2006 and 2007 data for each microclimate monitoring site and for the TNC and VMF weather stations as follows:

$$
\mathrm{GDD}=\sum[(\mathrm{T} \max +\mathrm{T} \min ) / 2]-4
$$


Table 1. Site, ownership, map code, site type, and river location for birch study sites in the Niobrara Valley.

[NGPC, Nebraska Game and Parks Commission; FWS, U.S. Fish and Wildlife Service; TNC, The Nature Conservancy]

\begin{tabular}{|c|c|c|c|c|c|}
\hline Site & Ownership & Map code & Study use & Site type & River location \\
\hline Borman Bridge & NGPC & 1111 & Microclimate and birch health & Canyon & Upper \\
\hline Fort Falls & FWS & 6567 & Microclimate and birch health & Riverfront & Upper \\
\hline Upper Coon Creek & FWS & 3333 & Birch health & North canyon & North side \\
\hline Coon Creek West & FWS & 3331 & Microclimate and birch health & North canyon & North side \\
\hline Coon Creek East & FWS & 3332 & Microclimate and birch health & North canyon & North side \\
\hline Buffalo Bridge & FWS & 1553 & Birch health & Riverfront & Upper \\
\hline Box Canyon & FWS & 4442 & Microclimate and birch health & North canyon & North side \\
\hline Side Canyon & FWS & 4441 & Microclimate and birch health & North canyon & North side \\
\hline Small Canyons & FWS & 4922 & Birch health & Riverfront & Upper \\
\hline Buffalo Fence & FWS & 4920 & Microclimate and birch health & Riverfront & Upper \\
\hline Tyler Falls & FWS & 2222 & Birch health & Canyon & Upper \\
\hline Wide Bend & FWS & 2223 & Birch health & Riverfront & Upper \\
\hline Smith Falls State Park & NGPC & 4208 & Microclimate and birch health & Canyon & Upper \\
\hline Brewer Bridge & $\mathrm{TNC}$ & 1721 & Birch health & Canyon & Upper \\
\hline Sharps Camp & $\mathrm{TNC}$ & 3450 & Birch health & Riverfront & Upper \\
\hline Rocky Ford & $\mathrm{TNC}$ & 6420 & Microclimate and birch health & Riverfront & Lower \\
\hline Cross Country & $\mathrm{TNC}$ & 1803 & Microclimate and birch health & Riverfront & Lower \\
\hline Dog Town & $\mathrm{TNC}$ & 1185 & Birch health & Riverfront & Lower \\
\hline Nature Trail & $\mathrm{TNC}$ & 5074 & Microclimate and birch health & Canyon & Lower \\
\hline Norden/Huddle & $\mathrm{TNC}$ & 7122 & Birch health & Canyon & Lower \\
\hline Garden Creek & $\mathrm{TNC}$ & 4865 & Birch health & Riverfront & Lower \\
\hline Kirkpatrick & $\mathrm{TNC}$ & 2302 & Birch health & Riverfront & Lower \\
\hline Jeff Creek & $\mathrm{TNC}$ & 6581 & Microclimate and birch health & Canyon & Lower \\
\hline Hartman Island & $\mathrm{TNC}$ & 6262 & Birch health & Canyon & Lower \\
\hline Lowest Site & TNC & 4468 & Birch health & Canyon & Lower \\
\hline
\end{tabular}

where

$\mathrm{T} \max =$ maximum temperature; and

$\mathrm{T} \min =$ minimum temperature in degrees Celsius on a given day.

This calculation method is similar to the 1971 National Oceanic and Atmospheric Administration formula, which uses $10{ }^{\circ} \mathrm{C}$ as a baseline for corn growth (Nielson, 2001). A baseline temperature of $4{ }^{\circ} \mathrm{C}$ was used because it represents the daily temperature above which biological activity occurs in yellow birch (Bourque and others, 2005) and because this temperature has been used as the threshold for biological activity when measuring injury to paper birch roots during periods of freezing temperatures followed by thaw (Braathe, 1995; Cox and Malcolm, 1997). The lowest daily temperatures recorded at each site during April and May 2006 and 2007 were selected to indicate that site's temperature minima. The same calculations were performed using VMF weather station data from 1948 to 2007 to examine Niobrara Valley thaw/freeze conditions from 1948 to 2007. Two-sample $t$ tests were used to test for differences in GDD means and a test for equality of two proportions was used to compare frequency of thaw/freeze years for the first one-half of the VMF 60 year period of record compared to the second one-half (Systat Software, Inc., 2004).

\section{Weather Reconstruction}

Daily weather data from 1948 to 2007 were used from the VMF weather station (approximately $44 \mathrm{~km}$ west-northwest of the TNC station) and from another NWS station at Ainsworth (AIN, approximately $32 \mathrm{~km}$ southeast of the TNC station) to reconstruct local weather conditions at TNC to 1948 (National Climatic Data Center, 2005-2007). Data from another nearby NWS station at Springview were incomplete and not used. Covariances and means were estimated using data from all three weather stations from April 13, 2005, to October 31, 2007, which was the period of data availability for the TNC station.

Daily mean values for minimum and maximum temperature at VMF and AIN from the NWS normal base period (1971 to 2000) were used to center (standardize) VMF and 
AIN temperature data from January 1, 1948, to October 31, 2007. Centering the values gives a more stable set of observations for use in Kalman filter and Kalman smoother models (Terrell, 1999). The Kalman filter and Kalman smoother are recursive models best used for sequential updating with linear model operators and Gaussian error distributions (Kalman, 1960; Cohn and others, 1994). The Kalman filter model uses data from a known starting point until time $t$ to reconstruct the climatic history for not only observed data but also missing data. The Kalman smoother considers all the data. For instance, estimates at time $t$ are based on information before and after that time point; thus, a backward recursion formula gives smoother distributions (Cohn and others, 1994). The centered values in Kalman filter and Kalman smoother models were used to estimate mean maximum and minimum temperatures for each day of the year at TNC. The modesl assume that climatic relation among the locations remain constant for the entire period of interest (January 1, 1948, through October 10, 2007).

A similar approach was used to reconstruct conditions at birch site 6567 (fig. 1, table 1) near Fort Falls using data from VMF and data from one of the Hobo data loggers (UPRI-1B). This site was selected because of its accessibility for continued microclimate monitoring. The overlapping period of record used for estimating means and covariances was June 17, 2005, to October 31, 2007.

\section{Birch Stand Conditions}

Twenty-five sites (table 1) for health assessment of birch stands were visited in May and June 2006 and 2007; the 12 stands in which microclimate was monitored, plus additional canyon and riverfront sites on the upper and lower river, and 1 additional north canyon site. Stand area was estimated by walking the perimeter and logging a polygon using a Thales MobileMapper Pro GPS (global positioning system) unit (Thales Navigation, Inc. Santa Clara, California). Within stand boundaries, birch seedlings [individuals less than one $\mathrm{m}$ tall and with stem diameter less than or equal to 2.5 centimeter $(\mathrm{cm})]$ and all live and all dead birch trees were counted using click-type counters. Each live birch tree was numbered with chalk. The goal was to sample at least 10 living and 2 dead trees per site; however, this varied because of availability of live trees as well as safety of terrain. If the number of live birch trees within a stand was less than or equal to 10 , all were assessed; otherwise, 8 live trees were selected using a random number table. These trees and two others were used for stand health assessment. In the riverfront sites, the easternmost and westernmost living birch trees were selected, and in the canyon sites, the living birches closest to the canyon top and canyon mouth were selected for assessment. These stand edge birches were selected in addition to the randomly chosen ones to cover the range of environmental gradients with each stand.

For each assessed tree, GPS location, aspect (degrees), and percent slope were recorded; diameter at breast height, in $\mathrm{cm}$ was measured for each living and each dead bole; and presence of any male and female catkins noted. Each tree was checked for evidence of the following common birch pests, pathogens, or damage, and extent if evidence was found: Armillaria root disease, bronze birch borer, leaf miners, birch anthracnose, Chondrostereum purpureum, ambrosia beetles, frost cracks, sooty mold, sapsucker holes, and storm damage. Each tree was assigned a health score according to a dieback classification category based on increasing severity of crown injury (Nash and Duda, 1951):

$1=$ Normal, apparently healthy tree;

$2=$ Trees with abnormally small, thin, curled, chlorotic foliage (any one or combination);

$3=$ Trees with bare or dead twigs, but with no dead branches;

$4=$ Trees with dead branches constituting less than onehalf the crown;

$5=$ Trees with over one-half the crown dead; or

$6=$ Foliage only on one to several trunk sprouts (less than $2.5 \mathrm{~cm}$ diameter); and

$7=$ Tree entirely dead

Basal area per hectare of all nearby trees was estimated using an English basal area factor (BAF) 10 on a Jim-Gem cruz-all angle gauge. If a dead birch tree was included in the cruz-all plot, a health assessment was performed on it, until two dead birch trees had been assessed per site. Pearson product-moment correlations were calculated between mean tree health per site and other site variables; analysis of variance (ANOVA) was used with post-hoc Tukey multiple comparisons to test for differences in birch health and other site variables among site types, site locations, and sample years. Least squares linear regression was used to test for association of birch health score with environmental distance (Systat Software, Inc., 2004).

\section{Results}

\section{Microclimate}

For maximum temperature, no sites differed except that Borman Bridge, Fort Falls, and Buffalo Fence sites had lower maximum temperatures compared to Coon Creek East and TNC (table 2). For diurnal range, all four of the north canyon sites, along with the TNC weather station, had higher values than all other birch sites and the VMF weather station (table 2). 
Table 2. Mean values and 95 percent confidence intervals for temperature variables in 12 birch stands and at 2 weather stations in the Niobrara River Valley, Nebraska, from January 1, 2006, through December 31, 2006.

[Within a column, first number is mean value; range in parentheses is 95 percent confidence interval; values followed by different letters have non-overlapping confidence intervals; T, temperature in degrees Celsius; TNC, The Nature Conservancy weather station; VMF, Valentine Miller Field weather station]

\begin{tabular}{lccccc}
\hline \multicolumn{1}{c}{ Site } & $\begin{array}{c}\text { Map code } \\
\text { (figs. 1, 2) }\end{array}$ & Mean T & Minimum T & Maximum T & Diunal T range \\
\hline Borman Bridge & 1111 & $9.2(8.4-10.0)$ & $2.8(2.0-3.5)$ & $16.4(15.6-17.3)$ & $13.7(13.3-14.0) \mathrm{a}$ \\
Fort Falls & 6567 & $8.9(8.1-9.7)$ & $2.1(1.3-2.8)$ & $16.2(15.4-17.1) \mathrm{a}$ & $13.9(13.8-14.6) \mathrm{a}$ \\
Coon Creek West & 3331 & $8.8(7.1-10.0)$ & $1.0(-0.1-2.1)$ & $17.3(16.0-18.6)$ & $16.3(15.6-16.9) \mathrm{b}, \mathrm{c}$ \\
Coon Creek East & 3332 & $9.2(8.1-10.3)$ & $1.7(0.6-2.8)$ & $18.6(17.3-19.9) \mathrm{b}$ & $16.9(16.3-17.6) \mathrm{b}$ \\
Box Canyon & 4442 & $9.5(8.4-10.6)$ & $2.2(1.1-3.2)$ & $20.8(19.5-22.1)$ & $18.6(17.8-19.4) \mathrm{b}$ \\
Side Canyon & 4441 & $8.6(7.5-9.7)$ & $1.4(0.3-2.5)$ & $17.6(16.3-17.8)$ & $16.2(15.5-16.8) \mathrm{b}, \mathrm{c}$ \\
Buffalo Fence & 4920 & $8.8(8.1-9.6)$ & $2.3(1.3-2.8)$ & $16.2(15.4-17.1) \mathrm{a}$ & $13.9(13.5-14.3) \mathrm{a}$ \\
Smith Falls State Park & 4208 & $9.2(8.4-10.0)$ & $2.8(2.0-3.5)$ & $16.8(15.9-17.7)$ & $14.0(13.6-14.4) \mathrm{a}$ \\
Rocky Ford & 6420 & $9.3(8.5-10.0)$ & $2.9(2.1-3.7)$ & $16.7(15.9-17.6)$ & $13.8(13.4-14.3) \mathrm{a}$ \\
Cross Country & 1803 & $9.3(8.5-10.1)$ & $2.3(1.5-3.1)$ & $16.5(15.7-17.3)$ & $14.1(13.8-14.6) \mathrm{a}$ \\
Nature Trail & 5074 & $9.3(8.5-10.1)$ & $3.0(2.3-3.8)$ & $16.7(15.9-17.6)$ & $13.7(13.3-14.1) \mathrm{a}$ \\
Jeff Creek & 6581 & $9.5(8.7-10.2)$ & $2.9(2.2-3.7)$ & $17.8(17.0-18.7)$ & $14.8(14.4-15.4) \mathrm{a}$ \\
TNC & none & $10.1(9.0-11.3)$ & $1.9(0.8-3.0)$ & $19.1(17.9-20.4) \mathrm{b}$ & $17.2(16.6-17.9) \mathrm{b}$ \\
VMF & none & $9.2(8.6-10.9)$ & $2.2(0.9-3.1)$ & $17.7(16.2-18.8)$ & $15.4(14.9-16.1) \mathrm{a}, \mathrm{c}$ \\
\hline
\end{tabular}

Environmental distance values between each microclimate site and the TNC weather station were smaller for minimum temperature than for maximum temperature and diurnal range (table 3). Environmental distance for diurnal range was correlated with maximum temperature distance $(\mathrm{r}=0.74)$ but only weakly correlated with minimum temperature distance $(\mathrm{r}$ $=0.44)$; maximum and minimum temperature distances were not correlated $(r=-0.09)$. March GDD and minimum April and May temperatures for the microclimate sites and both weather stations are given in table 4. March GDD values were much higher and May minimum temperatures much lower for all sites in 2007 as compared to 2006 values. In 2006, two north canyon sites (Coon Creek East and Box Canyon) and the TNC weather station had sufficiently warm March temperatures (GDD totals greater than 50) and sufficiently cold April minimum temperatures (less than $-4{ }^{\circ} \mathrm{C}$, table 4 ) to meet thaw/ freeze conditions capable of inducing rootlet injury. In 2007, every site met these thaw/freeze conditions (table 4).

March GDD and April and May minimum temperatures recorded at VMF weather station from 1948 through 2007 are given in table 5. Values for April and May minimum temperatures for the 30 year mean from 1948 to 1977 were identical to those for the 30 year mean from 1978 to 2007 (table 5); however, the March mean GDD for 1948 to 1977 was 34. This is significantly less than the mean March GDD value of 52 for 1978 to $2007(\mathrm{t}=-2.734, \mathrm{df}=58, \mathrm{p}=0.008)$. Years in which combinations of March GDD and April or May minimum temperatures met thaw/freeze conditions were more frequent in the latter part of the period of record. From 1948 to 1977 , thaw/freeze conditions were met in 7 years ( 23 percent), as compared to 15 years (50 percent) from $1978-2007$ (table 5); these proportions are significantly different $(\mathrm{z}=-2.179, \mathrm{p}=$ 0.029).

Confidence intervals for spring (March-May) and summer (June-August) temperature parameters for birch stands grouped by site type and river location along with TNC and VMF weather stations are shown in figures 3 and 4. In spring months (fig. 3), mean temperatures in all birch microclimate sites ranged from 8 to $9{ }^{\circ} \mathrm{C}$, overlapping with the lower end of TNC interval and the upper end of the VMF interval; therefore, no differences from either weather station could be discerned. Lower river sites were about $0.6^{\circ} \mathrm{C}$ warmer than upper river sites (fig. 3A). Lower river sites and canyon sites have higher spring maximum temperatures as compared to upper river and riverfront sites, and north canyon sites are the warmest of all locations (fig. 3B). The TNC station has higher spring maximum temperatures than VMF, and overlaps with the lower river sites, whereas VMF overlaps with canyon and riverfront sites (fig. 3B). For spring minimum temperatures, VMF and TNC overlap with all birch microclimate monitoring locations, but north canyon sites have lower daily minimum temperatures than all other birch stand types (fig. 3C). For spring diurnal range, lower river sites had a greater range than upper river sites, riverfront sites had about $0.3{ }^{\circ} \mathrm{C}$ smaller range than canyon sites, and north canyon sites had a much greater range than any other type or location (fig. 3D).

In summer months (fig. 4), mean temperature is similar in all birch microclimate monitoring locations, and all sites averaged $2{ }^{\circ} \mathrm{C}$ lower than TNC and VMF (fig. 4A). For summer maximum temperatures, TNC is the highest of all sites; north 
Table 3. Environmental distance in degrees Celsius between microclimate in 12 birch stands and a reference weather station in the Niobrara River Valley, Nebraska, for 3 temperature parameters from January 1, 2006, through December 31, 2006.

\begin{tabular}{lcccc}
\hline \multicolumn{1}{c}{ Site } & $\begin{array}{c}\text { Map code } \\
\text { (figs. 1, 2) }\end{array}$ & $\begin{array}{c}\text { Minimum } \\
\text { temperature }\end{array}$ & $\begin{array}{c}\text { Maximum } \\
\text { temperature }\end{array}$ & $\begin{array}{c}\text { Diurnal } \\
\text { temperature } \\
\text { range }\end{array}$ \\
\hline Borman Bridge & 1111 & 11 & 32 & 43 \\
Fort Falls & 6567 & 3 & 35 & 37 \\
Coon Creek West & 3331 & 10 & 25 & 21 \\
Coon Creek East & 3332 & 4 & 16 & 17 \\
Box Canyon & 4442 & 5 & 33 & 30 \\
Side Canyon & 4441 & 6 & 23 & 21 \\
Buffalo Fence & 4920 & 6 & 35 & 40 \\
Smith Falls State Park & 4208 & 11 & 28 & 39 \\
Rocky Ford & 6420 & 12 & 29 & 41 \\
Cross Country & 1803 & 6 & 33 & 38 \\
Nature Trail & 5074 & 14 & 30 & 43 \\
Jeff Creek & 6581 & 13 & 23 & 34 \\
\hline
\end{tabular}

Table 4. March growing degree days and lowest April and May daily minimum temperature in 12 birch stands and at 2 weather stations in the Niobrara River Valley for 2006 and 2007.

[Boldface indicates instances in which thaw/freeze conditions sufficient for inducing rootlet injury to birch trees were met; GDD, growing degree days; T min, minimum temperature in degrees Celsius; TNC, The Nature Conservancy weather station; VMF, Valentine Miller Field weather station]

\begin{tabular}{|c|c|c|c|c|c|c|c|}
\hline \multirow[b]{2}{*}{ Site } & \multirow[b]{2}{*}{$\begin{array}{c}\text { Map code } \\
\text { (figs. 1, 2) }\end{array}$} & \multicolumn{3}{|c|}{2006} & \multicolumn{3}{|c|}{2007} \\
\hline & & $\begin{array}{l}\text { March } \\
\text { GDD }\end{array}$ & $\begin{array}{l}\text { April } \\
\text { T min }\end{array}$ & $\begin{array}{l}\text { May } \\
\text { T min }\end{array}$ & $\begin{array}{l}\text { March } \\
\text { GDD }\end{array}$ & $\begin{array}{l}\text { April } \\
\text { T min }\end{array}$ & $\begin{array}{l}\text { May } \\
\text { T min }\end{array}$ \\
\hline Borman Bridge & 1111 & 24 & -5.7 & -0.8 & 108 & -13.0 & 4.7 \\
\hline Fort Falls & 6567 & 28 & -7.0 & -2.9 & 112 & -14.5 & 2.8 \\
\hline Coon Creek West & 3331 & 31 & -8.4 & -4.2 & 114 & -15.9 & 1.3 \\
\hline Coon Creek East & 3332 & 62 & -7.6 & -3.8 & 160 & -15.1 & 2.1 \\
\hline Box Canyon & 4442 & 92 & -6.6 & -2.9 & 217 & -14.6 & 3.2 \\
\hline Side Canyon & 4441 & 41 & -7.5 & -3.5 & 143 & -15.5 & 2.3 \\
\hline Buffalo Fence & 4920 & 30 & -6.8 & -1.5 & 117 & -14.0 & 3.4 \\
\hline Smith Falls State Park & 4208 & 43 & -5.2 & -1.7 & 140 & -13.9 & 3.8 \\
\hline Rocky Ford & 6420 & 45 & -5.5 & -1.0 & 145 & -13.1 & 3.6 \\
\hline Cross country & 1803 & 33 & -7.2 & -2.5 & 115 & -15.0 & 2.5 \\
\hline Nature Trail & 5074 & 45 & -5.8 & -1.7 & 142 & -13.8 & 3.3 \\
\hline Jeff Creek & 6581 & 25 & -6.2 & -2.1 & 121 & -13.8 & 2.1 \\
\hline TNC & none & 54 & -6.5 & -2.6 & 146 & -14.5 & .2 \\
\hline VMF & none & 39 & -6.7 & -2.8 & 132 & -13.9 & 2.8 \\
\hline
\end{tabular}


Table 5. March Growing Degree Days and lowest May minimum temperature at Valentine Miller Field from 1948 to 2007.

[GDD, growing degree days, using 4 degrees Celsius as baseline temperature; years in which thaw/freeze conditions were met are in boldface]

\begin{tabular}{|c|c|c|c|c|c|c|c|}
\hline Year & $\begin{array}{l}\text { March } \\
\text { GDD }\end{array}$ & $\begin{array}{c}\text { April } \\
\text { minimum }\end{array}$ & $\begin{array}{c}\text { May } \\
\text { minimum }\end{array}$ & Year & $\begin{array}{c}\text { March } \\
\text { GDD }\end{array}$ & $\begin{array}{c}\text { April } \\
\text { minimum }\end{array}$ & $\begin{array}{c}\text { May } \\
\text { minimum }\end{array}$ \\
\hline 1948 & 45 & -7 & 0 & 1978 & 55 & -6 & 1 \\
\hline 1949 & 23 & -7 & 1 & 1979 & 22 & -8 & -4 \\
\hline 1950 & 17 & -11 & -4 & 1980 & 15 & -7 & -6 \\
\hline 1951 & 14 & -11 & -2 & 1981 & 48 & -7 & -6 \\
\hline 1952 & 12 & -9 & -1 & 1982 & 40 & -11 & -2 \\
\hline 1953 & 57 & -7 & -3 & 1983 & 45 & -8 & -2 \\
\hline 1954 & 16 & -10 & -7 & 1984 & 19 & -7 & -6 \\
\hline 1955 & 35 & -5 & 0 & 1985 & 50 & -9 & -2 \\
\hline 1956 & 41 & -9 & -3 & 1986 & 96 & -11 & -1 \\
\hline 1957 & 16 & -13 & 0 & 1987 & 38 & -8 & 4 \\
\hline 1958 & 4 & -7 & -1 & 1988 & 49 & -9 & 1 \\
\hline 1959 & 33 & -12 & -3 & 1989 & 64 & -13 & -6 \\
\hline 1960 & 35 & -6 & -2 & 1990 & 40 & -13 & -5 \\
\hline 1961 & 32 & -12 & -2 & 1991 & 52 & -5 & -5 \\
\hline 1962 & 18 & -11 & -3 & 1992 & 52 & -12 & -2 \\
\hline 1963 & 84 & -8 & -3 & 1993 & 59 & -6 & -4 \\
\hline 1964 & 14 & -9 & -1 & 1994 & 56 & -9 & -2 \\
\hline 1965 & 6 & -2 & -1 & 1995 & 103 & -10 & 1 \\
\hline 1966 & 78 & -14 & -4 & 1996 & 20 & -11 & 1 \\
\hline 1967 & 86 & -8 & -7 & 1997 & 65 & -16 & -4 \\
\hline 1968 & 76 & -14 & -2 & 1998 & 44 & -5 & -1 \\
\hline 1969 & 8 & -4 & -3 & 1999 & 65 & -7 & -1 \\
\hline 1970 & 5 & -11 & -1 & 2000 & 56 & -8 & -2 \\
\hline 1971 & 32 & -7 & -1 & 2001 & 36 & -9 & 1 \\
\hline 1972 & 64 & -11 & -4 & 2002 & 13 & -15 & -4 \\
\hline 1973 & 33 & -12 & -3 & 2003 & 81 & -13 & -4 \\
\hline 1974 & 59 & -7 & 0 & 2004 & 86 & -9 & -3 \\
\hline 1975 & 19 & -16 & -1 & 2005 & 38 & -7 & -8 \\
\hline 1976 & 42 & -6 & -6 & 2006 & 33 & -7 & -3 \\
\hline 1977 & 25 & -4 & 3 & 2007 & 111 & 3 & -14 \\
\hline Mean & 34 & -9 & -2 & Mean & 52 & -9 & -2 \\
\hline
\end{tabular}

canyon sites are about $2{ }^{\circ} \mathrm{C}$ warmer than all other birch sites and similar to VMF (fig. 4B). Upper river sites were about 0.4 ${ }^{\circ} \mathrm{C}$ warmer than lower sites, and canyon sites are about $0.6^{\circ} \mathrm{C}$ warmer than river sites. For summer minimum temperatures, north canyon sites are similar to TNC and about $1{ }^{\circ} \mathrm{C}$ cooler than the other birch sites and VMF; upper river sites are about $0.3{ }^{\circ} \mathrm{C}$ cooler than lower sites (fig. $4 \mathrm{C}$ ). For summer diurnal range, all locations differ; in descending order, they are TNC, north canyon sites, VMF, upper river, canyon, riverfront, and lower river (fig. 4D). Summer diurnal temperature range in north canyon sites is about $3{ }^{\circ} \mathrm{C}$ greater than in other birch sites and about $1{ }^{\circ} \mathrm{C}$ greater and less than VMF and TNC.

\section{Weather Reconstruction}

The mean difference between the three combinations of weather station pairs (TNC, VMF, AIN) over the shared period (April 13, 2005 to October 31, 2007), and over the unobserved period where TNC information is not available (January 1, 1950 to April 12, 2005) is shown in table 6. Differences between VMF and AIN were similar for minimum 

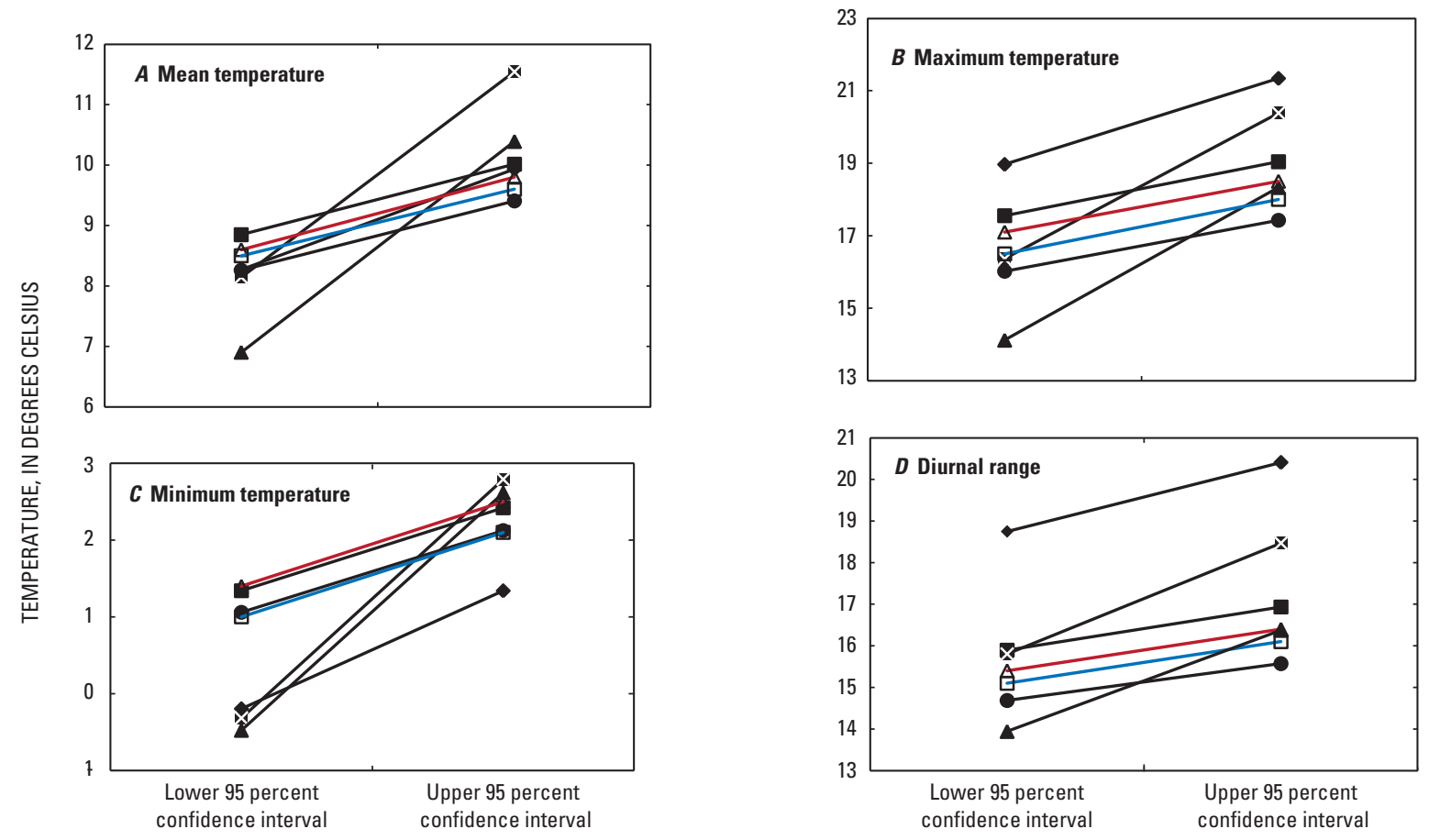

EXPLANATION

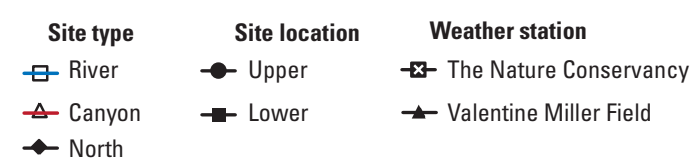

Figure 3. Ninety-five percent confidence intervals for four microclimate temperature parameters in Niobrara Valley birch stands for comparison by site type or site location and at two weather stations, March through May 2006.

and maximum temperature for the two periods. Maximum temperature average difference between TNC and the other stations decreased from the shared period to the unobserved period. This indicates that TNC temperatures for 1950 to 2005 were either underestimated or became smoother as the algorithms estimated retrospectively. For minimum temperature, mean difference between TNC and VMF increased 0.74 ${ }^{\circ} \mathrm{C}$, and the difference between TNC and AIN decreased 0.48 ${ }^{\circ} \mathrm{C}$ from the shared period to the unobserved period. Overall smoothing estimates had standard errors of $0.52{ }^{\circ} \mathrm{C}$ for mean minimum temperature and $0.54{ }^{\circ} \mathrm{C}$ for mean maximum temperature, which is larger than the estimated change in minimum temperature between TNC and AIN. Decreases in mean maximum temperature differences of approximately $1^{\circ} \mathrm{C}$ and $1.5^{\circ} \mathrm{C}$ (TNC-AIN and TNC-VMF) from shared period to the projected are larger than the standard error and represent detectable differences (table 6). Maximum temperature at TNC was likely higher than at both VMF and AIN from 1950 to 2005; minimum temperatures at TNC were probably higher than AIN but not VMF for the same period based on projected TNC values. Mean minimum temperature at TNC was similar to VMF and $1.43^{\circ} \mathrm{C}$ warmer than AIN for the shared period April 2005 to October 2007; mean maximum temperature at
TNC was about $2{ }^{\circ} \mathrm{C}$ warmer than both VMF and AIN during this time (table 6). Maximum and minimum temperature differences between TNC and VMF for the shared period are similar to those for calendar year 2006 (table 2), indicating that climatic relations were similar for a 27 month period as compared to a 12 month part of that period.

Diurnal temperature range from the shared period is shown for all three stations in figure 5. The diurnal temperature range observed at TNC is more similar to VMF, and much greater than diurnal temperature range observed at AIN during most of the shared period. This indicates that the algorithm for estimating the TNC temperatures is better with VMF data alone than with both VMF and AIN data.

Diurnal temperature differences between VMF and the UPRI-1B monitor in a birch stand near Fort Falls (site 6567, fig. 1, table 1) for four seasonal periods in 2006 and 2007 are shown in figures 6 through 9. Diurnal temperature at UPRI1-B as compared to VMF was somewhat smaller in winter months (December, January, and February, fig. 6) and considerably smaller in summer (June through August, fig. 8). In the fall, (September, October, and November, fig. 9) diurnal temperature range at UPRI-1B was smaller in the early months and nearly equal at the end of the period. The average diurnal 


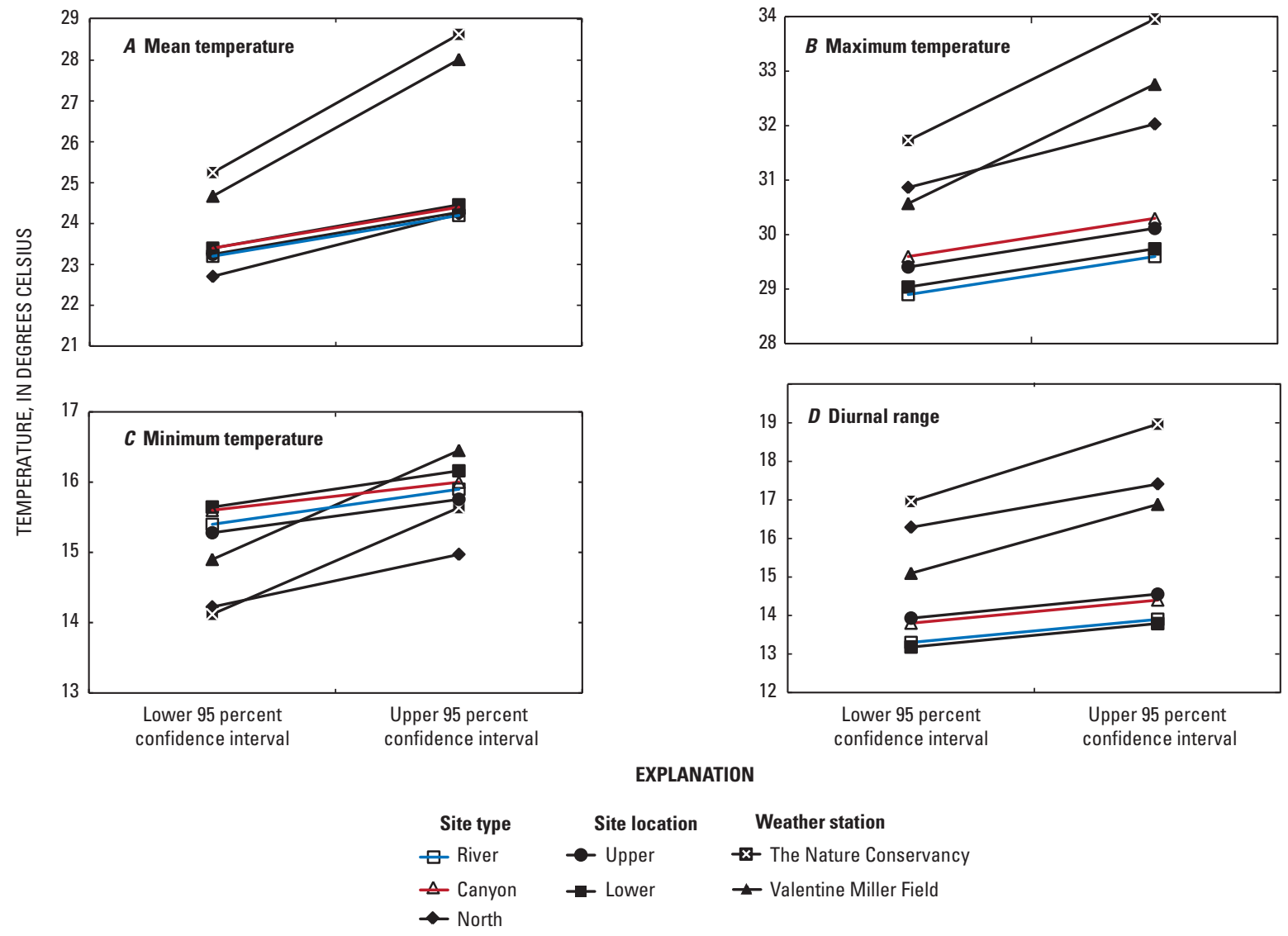

Figure 4. Ninety-five percent confidence intervals for four temperature parameters in Niobrara Valley birch stands for comparison by site type or site location and at two weather stations, June through August 2006.

Table 6. Mean differences between each of three weather station pairs for periods where they shared data (4/13/05 to 10/31/07) and where only modeled smoothing estimates are available (1/1/50 to 4/12/05).

T, temperature in degress Celsius; VMF, Valentine Miller Field; AIN, Ainsworth; TNC, The Nature Conservancy.

\begin{tabular}{ccccc}
\hline $\begin{array}{c}\text { Weather } \\
\text { station }\end{array}$ & $\begin{array}{c}\text { Minimum T } \\
\text { difference }\end{array}$ & $\begin{array}{c}\text { Maximum T } \\
\text { difference }\end{array}$ & $\begin{array}{c}\text { Minimum T } \\
\text { difference }\end{array}$ & $\begin{array}{c}\text { Maximum T } \\
\text { difference }\end{array}$ \\
\hline & $4 / 13 / 05$ to & $10 / 31 / 07$ & $1 / 1 / 50$ to & $4 / 12 / 05$ \\
\hline VMF - AIN & -1.70 & 0.33 & -1.91 & -0.24 \\
TNC - VMF & -.27 & 1.86 & -1.01 & .30 \\
TNC - AIN & 1.43 & 1.52 & .95 & .53 \\
\hline
\end{tabular}

range in late spring. Recursive model estimates showed increasing decadal differences (UPRI1-B minus VMF) in minimum temperatures between the birch stand near Fort Falls and VMF from 1950 to 1980 , steady differences for 1980 to 1990 , and decreasing differences from 1990 to 2000 (fig. 10A). These differences range from approximately 0.1 to $0.6{ }^{\circ} \mathrm{C}$. Differences in maximum temperature were larger $\left(0.8\right.$ to $\left.1.4^{\circ} \mathrm{C}\right)$ and increased sharply from 1960 to 1980 , decreased slightly from 1980 to 1990 , and increased slightly again from 1990 to 2000 (fig. 10B). temperature range for UPRI1-B was highest during March to May with a mean of $15.4{ }^{\circ} \mathrm{C}$ during 2006 and $14.2^{\circ} \mathrm{C}$ during 2007 (fig. 8). The smallest difference was in the summer and winter, with average diurnal temperature range of about $13.5^{\circ} \mathrm{C}$ during 2006 and $12.1{ }^{\circ} \mathrm{C}$ during 2007. Diurnal range at Fort Falls is about the same as VMF in the early spring but rather higher in late spring (fig. 7). This indicates that VMF may be a good predictor for early spring conditions in the birch stand at Fort Falls, but may underestimate temperature

\section{Birch Stand Conditions}

Twenty-five birch stands were sampled; 16 in 2006 and 9 in 2007. The number of birch trees per site ranged from seven at the Coon Creek West site to 94 at the Brewer Bridge site (table 7). Steep terrain at Wide Bend prevented a complete count of all birch trees; site size was estimated by digitizing the area around the GPS coordinates of assessed trees. Number of trees sampled per site ranged from 4 to 15 (table 7). 


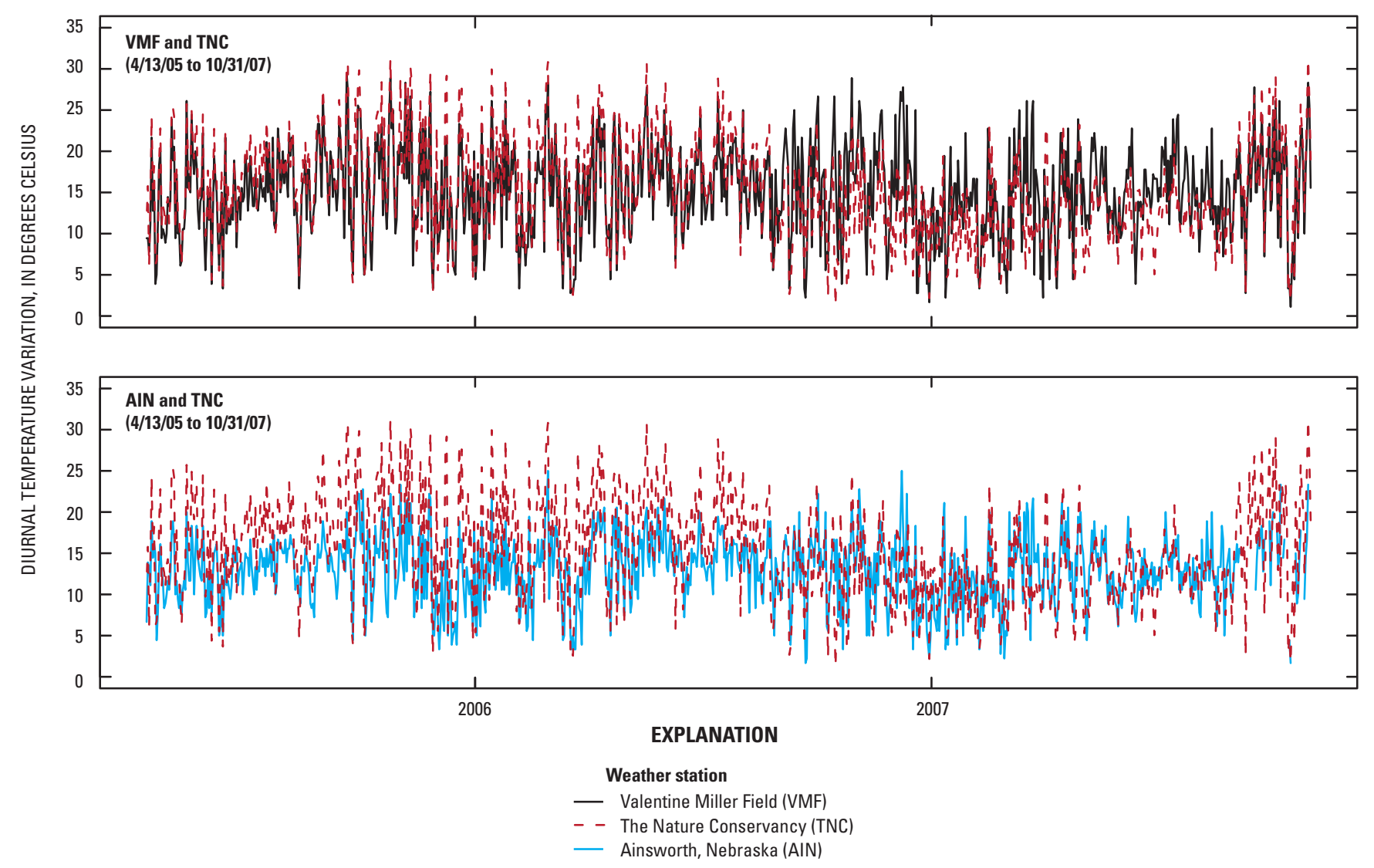

Figure 5. Observed diurnal temperature variation for weather stations.

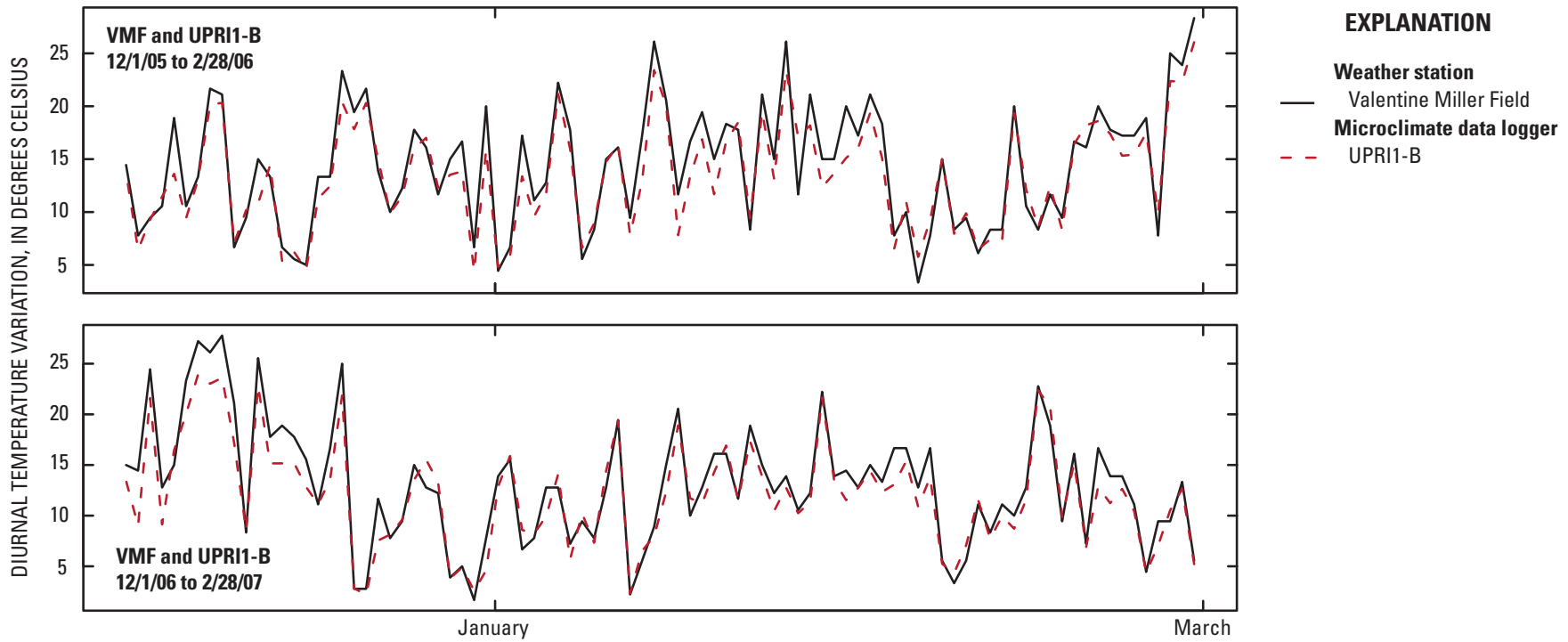

Figure 6. Observed winter diurnal temperature variation for one weather station and one data logger. 


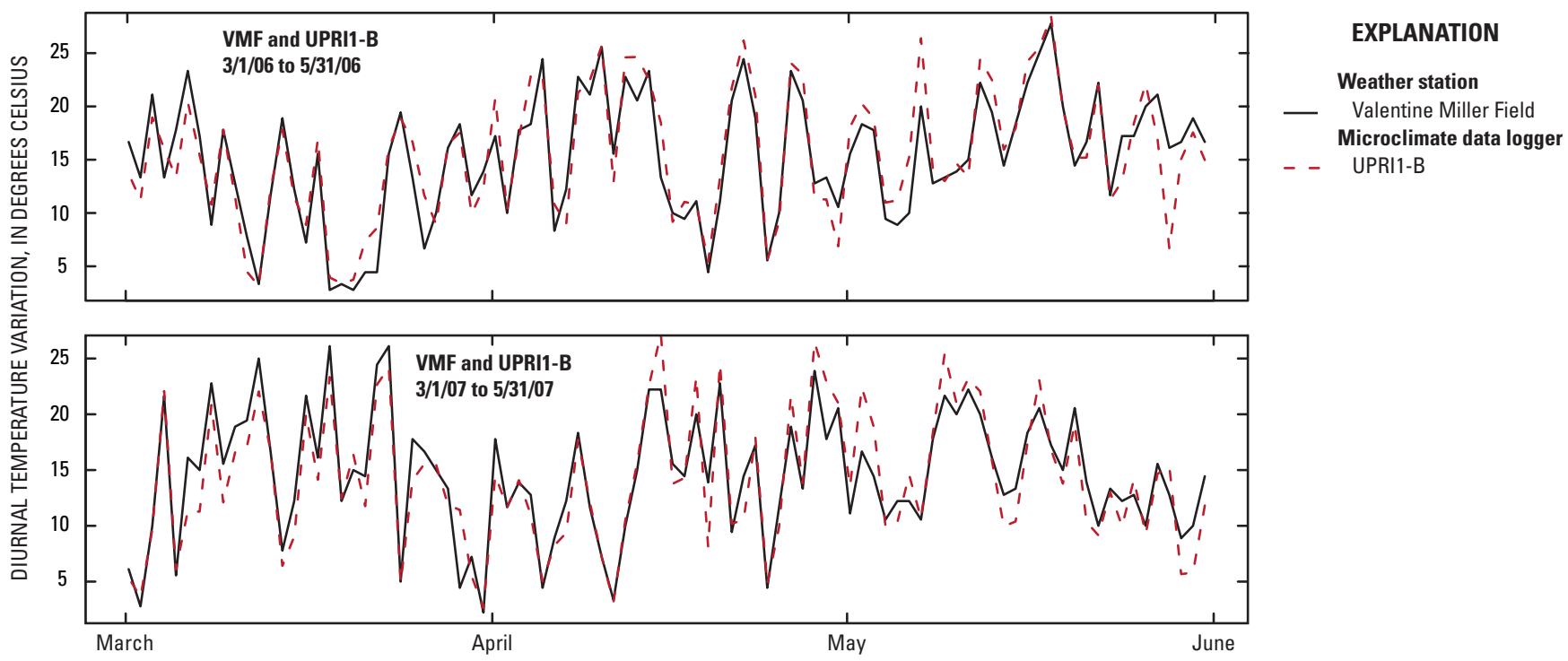

Figure 7. Observed spring diurnal temperature variation for one weather station and one data logger.

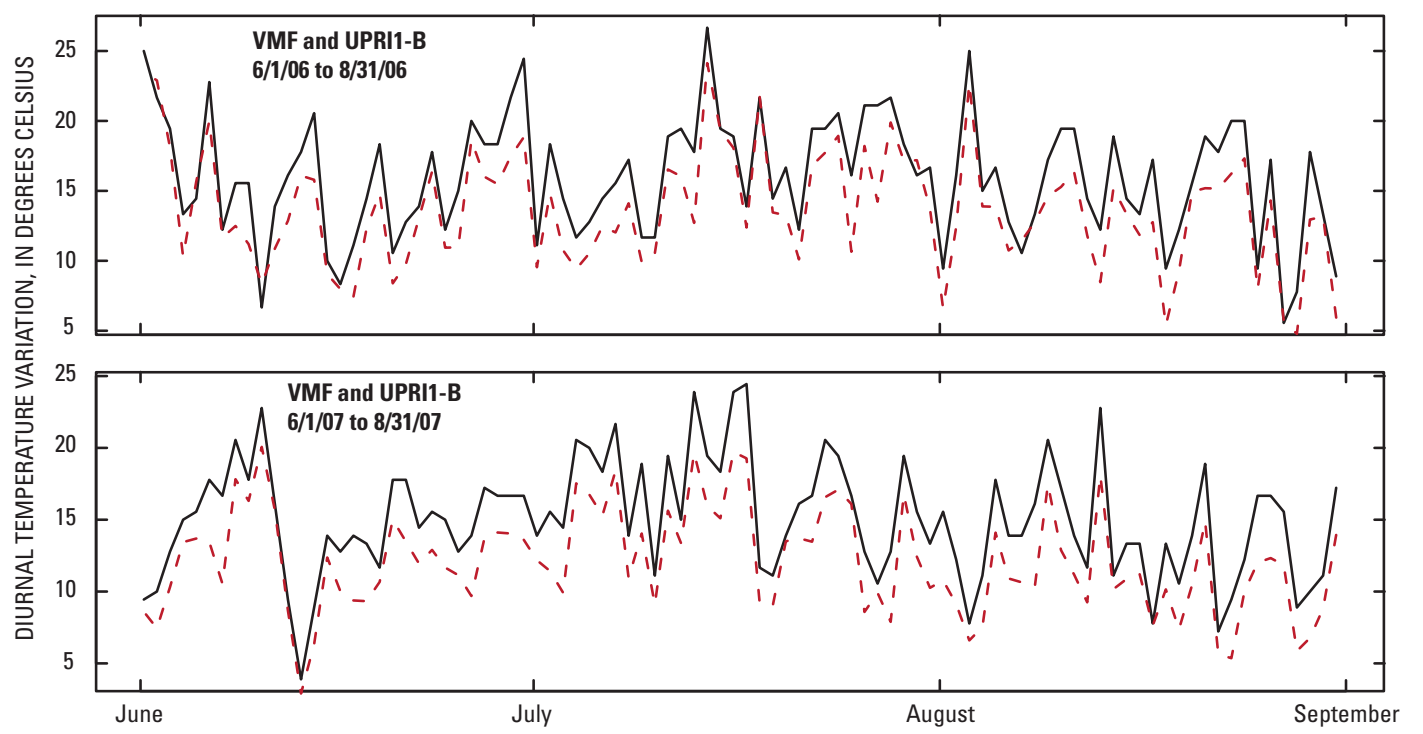

EXPLANATION

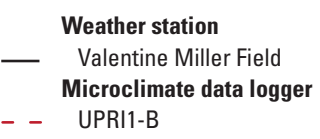

- UPRI1-B

Figure 8. Observed summer diurnal temperature variation for one weather station and one data logger.

Percentage of living birch per site was lowest (20 percent) at the Box Canyon site and highest ( 88 percent) at the Buffalo Bridge site. Mean health score $(1=$ healthy, $7=$ completely dead) ranged from 3.9 at the Tyler Falls site to 6.5 at the Box Canyon site (table 7). For the healthiest site, the mean value 3.9 corresponds most closely to the condition of having dead branches but less than one-half of the crown dead. For the least healthy site, the mean value of 6.5 is midway between the condition of having foliage on only one to several small trunk sprouts (6) to an entirely dead tree (7).
Stand area ranged from 0.02 to 2.77 ha (hectares); birch basal area per hectare was lowest at Jeff Creek [0.6 square meter per hectare $\left.\left(\mathrm{m}^{2} / \mathrm{ha}\right)\right]$ and highest at Coon Creek West $\left(19.3 \mathrm{~m}^{2} / \mathrm{ha}\right.$, table 7$)$. The percentage of birch basal area comprised of living boles was greatest at the Wide Bend site (97 percent) and lowest at the Side Canyon site (1 percent). Birch trees are prolific sprouters, and individual trees often consist of multiple stems. Mean number of boles per tree ranged from 1.5 at the Sharp's Camp site to 5.2 at the Upper Coon Creek site (table 7). The number of boles per tree was not correlated 


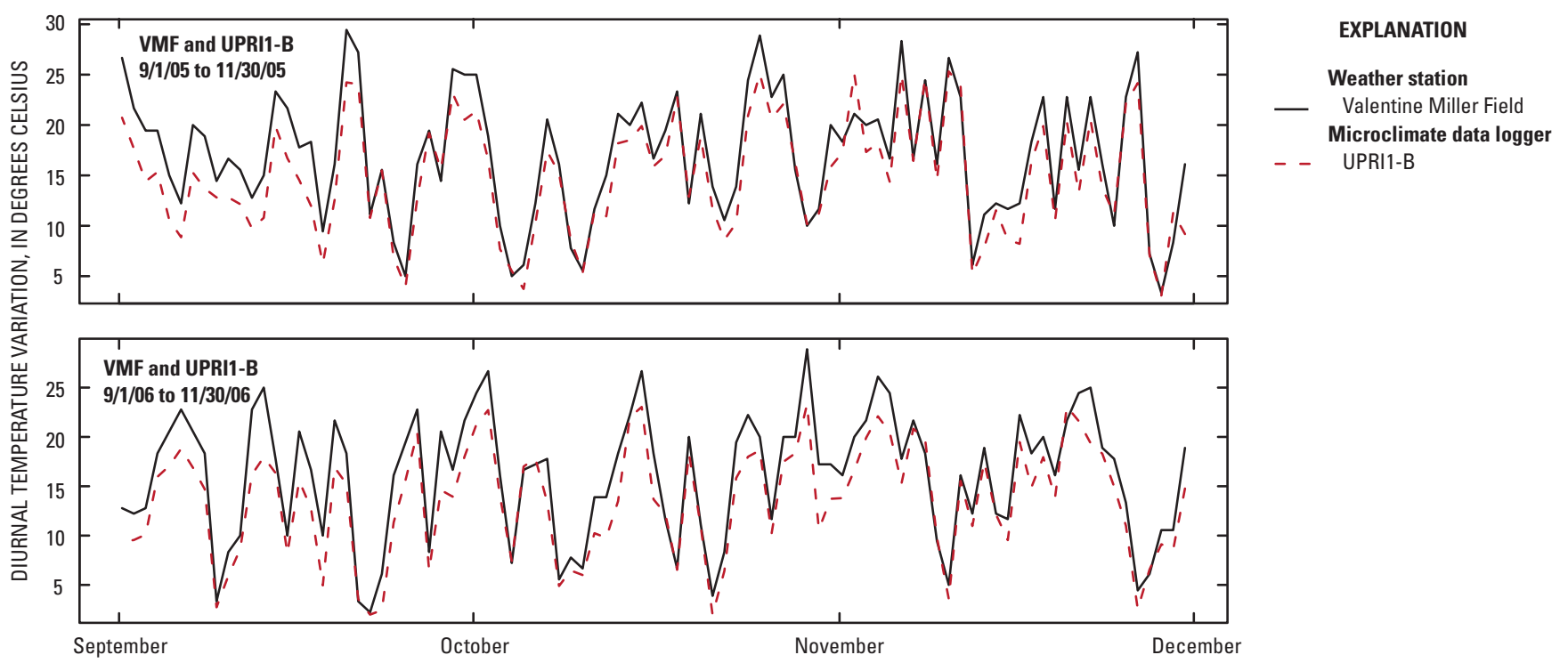

Figure 9. Observed fall diurnal temperature variation for one weather station and one data logger.

with mean health score $(\mathrm{r}=0.11)$; however, a slight negative correlation existed between percentage of live trees in sites and number of boles per tree $(r=-0.35)$, perhaps indicating sprouting as a response to undesirable conditions.

No evidence of any birch pest or pathogen was detected in any stand except for bronze birch borer. The presence of D-shaped exit holes were considered as evidence of birch borer activity (Krischik and Davidson, 2006). Percentage of assessed trees per site with this condition are shown in table 7. Birch borer was not associated with site type $(\mathrm{F}=1.45, \mathrm{df}$ $=2,22, \mathrm{p}=0.34)$ or location $(\mathrm{F}=0.48 ; \mathrm{df}=2,22 ; \mathrm{p}=0.63)$. Likewise, stand type was not associated with any other birch health parameter. River location was associated only with health score $(\mathrm{F}=3.72 ; \mathrm{df}=2,22 ; \mathrm{p}=0.04)$. Upper river sites had significantly lower health score (healthier trees) than north canyon sites. Although upper river sites had lower mean health scores (healthier trees) than lower river sites, the difference was not statistically significant $(\mathrm{p}=0.21)$.

Sites did not differ by sample year (2006 and 2007) for percentage live trees $(\mathrm{t}=1.50, \mathrm{df}=23, \mathrm{p}=0.15)$, health score $(\mathrm{t}=-0.68, \mathrm{df}=23, \mathrm{p}=0.50)$, or percentage birch borer $(\mathrm{t}=$ $0.38, \mathrm{df}=23, \mathrm{p}=0.71)$. Sites differed by year for percentage reproductive trees, with more trees flowering in 2007 (mean = 24.5 percent) compared to 2006 (mean $=6.4$ percent; $\mathrm{t}=-2.53$, $\mathrm{df}=23, \mathrm{p}=0.02$ ). No birch seedlings were observed in any site; saplings not clearly emanating from birch stumps were observed at only two sites: one at Taylor Falls and six at the Rocky Ford site. The Taylor Falls sapling was in the bottom of the canyon at the edge of the flowing creek; the Rocky Ford saplings were closely grouped at the edge of the riverbank.

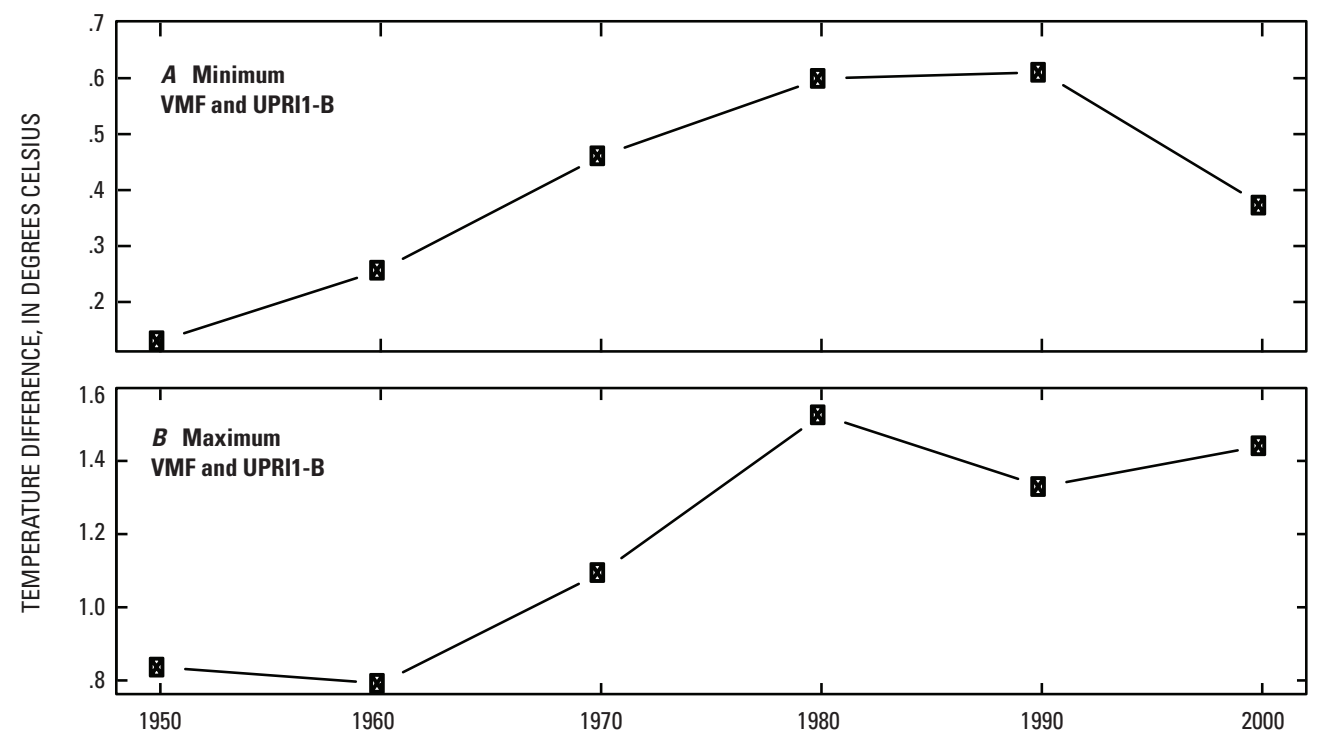

Figure 10. Average decadal absolute value difference between smoothing estimates for one weather station and one data logger for $\boldsymbol{A}$, minimum temperature and $\boldsymbol{B}$, maximum temperature. 


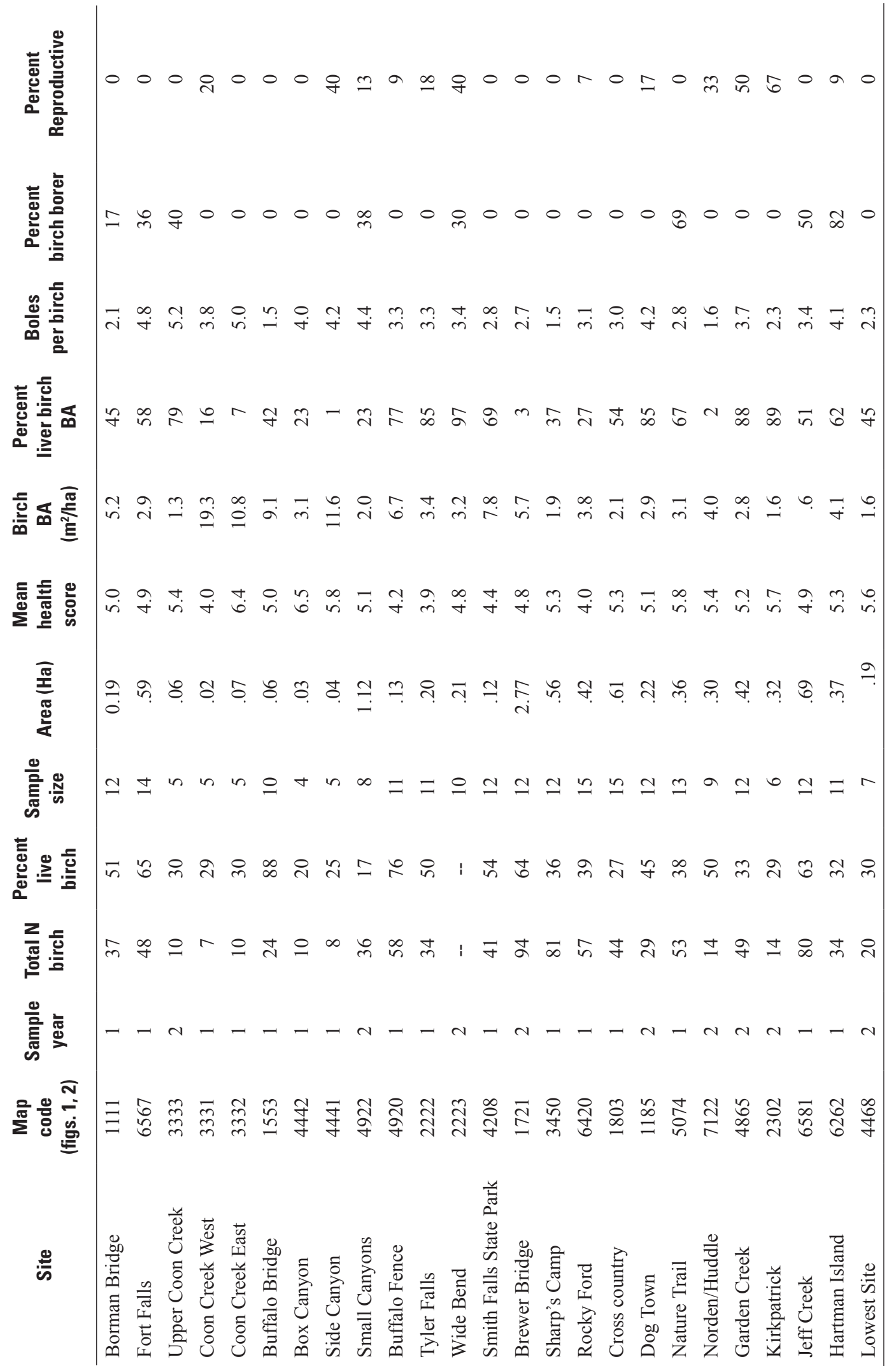


A group of nine saplings was observed at Smith Falls State Park outside the boundaries of the study site and within $10 \mathrm{~m}$ of two mature birch trees that produced seed in 2005, 2006, and 2007.

Birch condition was associated with some microclimate variables recorded in the stands. Pearson correlations for environmental distance (ED) of minimum temperature, maximum temperature, and diurnal range with percentage live birch were $0.59,0.35$ and -0.15 . For the strongest of these, ED of minimum temperature, a least-squares linear regression showed 36 percent of the variation in percentage of living birch was associated with ED from the TNC weather station $\left(r^{2}=0.361\right.$, $p=0.039$; fig. 11). Sites with daily minimum temperature profiles more similar to the TNC station climate tended to have a smaller proportion of living birch.

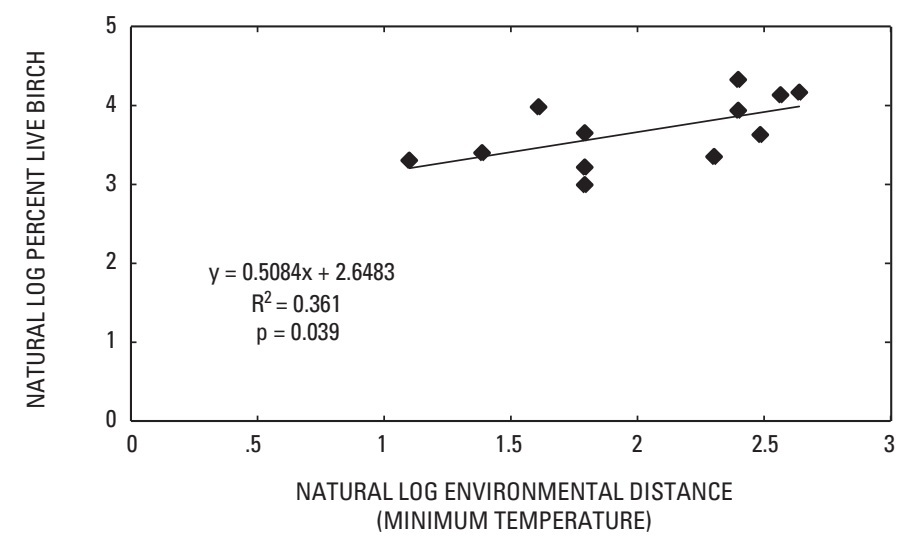

Figure 11. Relations between percentage living trees in 12 birch stands to environmental distance of site minimum temperature from The Nature Conservancy site minimum temperature, January 1 through December 31, 2006.

\section{Summary and Conclusions}

In this study, birch stand microclimate differed from local weather stations as well as among stands. None of the annual temperature parameters differentiated all birch stands from nearby weather stations, except that annual diurnal range was greater in north canyon birch sites and at the TNC station as compared to other birch sites and the VMF station. In addition, birch health was associated with annual minimum temperature regimes. Stands whose annual daily minimum temperature regimes were most like that of the TNC station contained smaller proportions of living trees. The TNC station is located in the lower part of the study area, and its microclimate is most similar to north canyon and lower river sites. These sites tend to have lower minimum temperatures and greater diurnal temperature range.

Growing season data were more effective than annual data for differentiating microclimate in birch stands as a group and among birch stand types and locations. In summer, daily maximum temperature and diurnal range separate birch stands from each other and from the local weather stations at TNC and VMF. All birch stands had mean summer temperatures of approximately $22{ }^{\circ} \mathrm{C}$, which is $1{ }^{\circ} \mathrm{C}$ cooler than the local weather stations and closer to the $21^{\circ} \mathrm{C}$ July maximum temperature range limit for birch (U.S. Department of Agriculture, 1965). Localized microclimates in the birch stands have likely facilitated the persistence of the birch populations in a region otherwise unsuitable for the species.

In the spring, higher daily minimum temperatures, lower daily maximum temperatures, and smaller diurnal range differentiate the more common canyon and riverfront sites on the Niobrara's south bank from north canyon sites. Among south bank sites, those in the upper part of the study area have lower daily mean, maximum, and minimum temperatures as well as a smaller diurnal range as compared to stands along the lower river portion. These microclimate differences may reduce the frequency of thaw/freeze conditions that can induce root injury and potential crown dieback in south bank birch stands relative to north bank sites, and, along the south bank, in upper river sites compared to lower river sites. Indeed, trees in upper river stands exhibited a smaller proportion of crown dieback than north bank and lower river sites (although the difference was significant only from north bank sites). During spring 2006 and 2007, thaw/freeze conditions were met in both years at TNC and in two of the four north canyon sites and in all locations in 2007. Suppressed, or sub-canopy trees, die back at lower rates than the more exposed canopy trees (Nash and Duda, 1951). In our study, extremely few small trees were found, so this observation could not be confirmed for birch trees in the Niobrara River Valley. The few healthy trees found in north canyon sites were small trees, some of them reproductive.

Low flowering rates can partly explain the paucity of young birch trees in the stands. These birch populations may be persisting primarily through vegetative reproduction (sprouting) of mature trees. Population persistence by vegetative reproduction for long periods is not uncommon in relict populations (Eriksson, 1996). Extremely rare recruitment events paired with vegetative reproduction in intervening years may be sufficient to maintain relict populations for many generations (Eriksson, 1996; Picó and Riba, 2002; García, 2003). In the case of the Niobrara paper birch, however, dieback of mature trees and loss of over 90 percent of trees in some stands will reduce the pool of individuals capable of continued sprouting until recruitment conditions might again be favorable. The increased rate of flowering in 2007 as compared to the rate in 2006 is not unusual for birch, which produce widely variable seed crops from year to year, with good crops in approximately 1 out of 4 years (Perala and Alm 1990). Catkins are established in the previous fall, so increased flowering in 2007 is not necessarily a response to the thaw/freeze conditions of that year.

Unlike birch populations in Canada and the northeastern United States that recovered from severe dieback events in the mid $20^{\text {th }}$ century (Auclair 2005), populations in the Niobrara River Valley are far removed from other potential immigrant 
sources. Recent models developed by Iverson and others (2008a, 2008b) under various climate change scenarios predict that paper birch is among the most likely species to lose suitable habitat area in the future. Although their predictions were for eastern United States forests, models of paper birch distribution had high reliability, and the top two variables defining the model were mean May through September temperature and mean annual temperature (Iverson and others, 2008a). Sites in the Niobrara River Valley had an annual mean temperature from 8.6 to $10.1{ }^{\circ} \mathrm{C}$ in 2006 (table 2) as compared to the eastern birch distribution model annual mean temperature of $5.1^{\circ} \mathrm{C}$ (Prasad and others, 2007). Annual mean temperature at VMF for 1948 through 2007 was $8.5^{\circ} \mathrm{C}$.

Birch stand microclimate differed significantly from local weather stations for summer mean temperatures; this also is true for summer maximum temperature and diurnal range, except for north canyon sites; therefore, if birch range is primarily limited by summer maximum temperature less than $21{ }^{\circ} \mathrm{C}$ (U.S. Department of Agriculture, 1965), these sites seem capable of continued support of birch trees. However, other factors besides summer maximum temperature can affect birch health, especially spring weather conditions. In the spring, birch stand microclimate is not significantly different from the local weather station at VMF. The weather station at VMF showed increased frequency of thaw/freeze events during the past 30 years; in spite of favorable summer conditions, this may be a key factor contributing to dieback of birch trees in the Niobrara River Valley.

The paper birch in the Niobrara River Valley have existed for perhaps 10,000 years in a climate setting that is outside the typical climate envelope for the species, but early spring thaw/ freeze conditions that can contribute to canopy dieback are increasing in frequency in recent years. Microclimate conditions in south bank birch stands are likely to experience less frequent thaw/freeze conditions than north canyon stands. However, early spring microclimate in riverfront and canyon sites on the south bank is similar enough to VMF that these sites likely experience thaw/freeze conditions with approximately the same frequency as VMF. Auclair (2005) suggested that forest tree species, including paper birch, exhibit cyclic population dieback events; this may explain, in part, the dieback event in progress in the Niobrara River Valley. However, a large population decline in the context of increased frequency of potentially injurious climatic events would make population recovery much more difficult currently (2009) than in the years 1948 to 1977, when thaw/freeze conditions were less frequent. These conditions, combined with little evidence of recruitment of young birch and great geographic distances from potential immigrant sources, make the future persistence of paper birch populations in the Niobrara River Valley uncertain.

\section{Management Implications}

No difference in mean health score existed in sites assessed in 2006 as compared to the score in 2007, even though all sites experienced thaw/freeze conditions in 2007. Crown effects from thaw/freeze root injury possibly are not fully expressed in the same year. Additional monitoring of birch stand condition will help to understand how the frequency of thaw/freeze conditions relates to changes in stand condition with time.

Birch populations in the study sites can be reassessed to document stable, improving, or worsening conditions. Tallies of live and dead trees within a stand is a simple way to track stand condition, but a tree must completely die before it changes the metric. Classifying trees according to percentage crown dieback using the system described in this report is more labor intensive but can indicate incremental changes in condition. Although many trees will likely continue to die back, individual trees can improve if living boles continue to grow.

Documenting the frequency of thaw/freeze conditions can assist in a birch stand health monitoring program. Fort Falls tends to have lower March GDD and approximately equivalent April and May minimum temperature values as compared to other birch sites, so spring thaw/freeze conditions here can signal more extreme conditions in other birch stands. For spring thaw conditions, VMF data can be used to estimate GDD at Fort Falls, and by extension, other south bank birch stands. Likewise, data from the TNC weather station can be used to estimate GDD in north bank birch stands. Either TNC or VMF data can be used to estimate spring minimum temperatures in birch sites to examine freeze potential. Continued monitoring at the Fort Falls site can provide data that will indicate which years are meeting these conditions and can inform a birch stand health monitoring plan.

Recruitment of birch was observed near the Smith Falls State Park site and in the Taylor Falls and Rocky Ford sites. Attempts to encourage birch seedling establishment by mechanical removal of surface litter and overstory canopy in birch stands met with some limited success in the Niobrara River Valley (Steuter and Steinauer, 1993). To attempt to propagate seedlings in a greenhouse or nursery may be more efficient. Likewise, cuttings from stems can be rooted to propagate clones of existing trees (Hares, 1968, as cited in Hannah, 1988). Young seedlings could then be planted in the stand. This type of assisted recruitment could help maintain populations of young trees that could perhaps grow to maturity and help maintain a seed source in sites for potential future natural recruitment. An attempt at propagation would complement a birch health monitoring program. 


\section{References Cited}

Auclair, A.N.D., Lill, J.T., and Revenga, C., 1996, The role of climate variability and global warming in the dieback of northern hardwoods: Water Air Soil Pollution, v. 91, p. $63-186$.

Auclair, A.N.D., 2005, Patterns and general characteristics of severe forest dieback from 1950 to 1995 in the northeastern United States: Canadian Journal of Forest Research, v. 35 p. 1,342-1,355.

Billings, W.D., and Anderson, L.E., 1966, Some microclimatic characteristics of habitats of endemic and disjunct bryophytes in the southern Blue Ridge: Bryologist, v. 69, p. 76-95.

Bourque, C.P-A., Cox, R.M., Allen, D., Arp, P., and Meng, F-R., 2005, Spatial extent of winter thaw events in eastern North America: Historical weather records in relation to yellow birch decline: Global Change Biology, v. 11(9), p. $1,477-1,492$.

Braathe, P., 1995, Birch dieback-caused by prolonged early spring thaws and subsequent frost: Norwegian Journal of Agricultural Sciences, Supplement No. 20, Norwegian Forest Research Institute, Ás, Norway, 59 p.

Christensen, J.H., Hewitson, B., Busuioc, A., Chen, A., Gao, X., Held, I., Jones, R., Kolli, R.K., Kwon, W.-T., Laprise, R., Magaña Rueda, V., Mearns, L., Menéndez, C.G., Räisänen, J., Rinke, A., Sarr, A., and Whetton, P., 2007, Regional Climate Projections, in Solomon, S., Qin, D., Manning, M., Chen, Z., Marquis, M., Averyt, K.B., Tignor, M., and Miller, H.L., (eds.), Climate Change 2007: The Physical Science Basis, Contribution of Working Group I to the Fourth Assessment Report of the Intergovernmental Panel on Climate Change: Cambridge University Press, Cambridge, United Kingdom, 996 p.

Cohn, S.E., Sivakumaran, N.S and Todling, R.,1994, A fixedlag Kalman smoother for retrospective data assimilation: Monthly Weather Review, v. 122 (12), p. 2,838-2,867.

Cox, R.M., and Malcolm, J.W., 1997, Effects of duration of a simulated winter thaw on dieback and xylem conductivity of Betula papyrifera: Tree Physiology, v. 17, p. 389-396.

Eriksson, O., 1996, Regional dynamics of plants: a review of evidence for remnant, source-sink and metapopulations: Oikos, v. 77, p. 248-258.

García, M., 2003, Demographic viability of a relict population of the critically endangered plant, Bordera chouardii: Conservation Biology, v. 17, p. 1,672-1,680.
Greenidge, K.N.H., 1953, Further studies of birch dieback in Nova Scotia: Canadian Journal of Botany, v. 31, p. 548559.

Hannah, P.R., 1988, Vegetative propagation of yellow birch from stem cuttings: Tree Planters Notes, Spring, p. 37-42.

Hares, R.I., 1968, Betula species from cuttings: Proceedings of the International Plant Propagators' Society, v. 18, p. 66-67.

Iverson, L.R., Prasad, A.M., and Matthews, M., 2008a, Modeling potential climate change impacts on the trees of the northeastern United States: Mitigation and Adaptation Strategies for Global Change, v. 13, p. 487-516.

Iverson, L.R., Prasad, A.M., Matthews, S.N., and Peters, M., 2008b, Estimating potential habitat for 134 eastern US tree species under six climate scenarios: Forest Ecology and Management, v. 254, p. 390-406.

Kalman, R.E., 1960, A new approach to linear filtering and prediction problems: Transactions of the ASME-Journal of Basic Engineering, v. 82 (Series D), p. 35-45.

Kaul, R.B., Kantak, G.E., and Churchill, S.P., 1988, The Niobrara River valley, a postglacial migration corridor and refugium of forest plants and animals in the grasslands of central North America: The Botanical Review, v. 54, p. 44-75.

Krischik,V.J., and Davidson, J., 2006, Bronze birch borer: Insect pests of ornamentals and their management: University of Minnesota Center for Urban Sustainability, factsheet, 2 p., accessed May 2006 at http://www.entomology.umn. edu/cues/Web/081BronzeBirchBorer.pdf

Nash, R.W., and Duda, E.J., 1951, Studies on extensive dying, regeneration, and management of birch: Maine Forest Service, Augusta, Bulletin No. 15, 82 p.

National Climatic Data Center, 2005-2007, Cooperative data/record of climatological observations for Valentine, Nebraska 1948-2007, accessed November 2007 at http://www4.ncdc.noaa.gov/cgi-win/wwcgi. dll?wwDI StnSrch StnID 20013446

National Weather Service, 2008, National Weather Service Weather Forecast Office, North Platte. Neb., Local climate data for Valentine, Neb., accessed September 21, 2008, at http://www.crh.noaa.gov/lbf/? $n=$ localclimatedata

Nielsen, R.L., 2001, What exactly do you mean by growing degree day? Purdue University Department of Agronomy, accessed June 2006 at http://www.agry.purdue.edu/ext/corn/ news/articles.01/Corn_GDD_Calc-0423.pdf

Perala, D.A., and Alm, A.A., 1990, Reproductive ecology of birch: A review: Forest Ecology and Management, v. 32, p. 1-38. 
Picó, F.X., and Riba, M., 2002, Regional-scale demography of Ramonda myconi: Remnant population dynamics in a preglacial relict species: Plant Ecology, v. 161, p. 1-13.

Pomerleau, R., 1991, Experiments on the causal mechanisms of dieback on deciduous forests in Québec: Québec Region Canadian Forest Service, Information Report LAU-X-96, $47 \mathrm{p}$.

Prasad, A. M., Iverson, L. R., Matthews, S., and Peters, M., 2007, Climate change tree atlas: A spatial database of 134 forest tree species of the eastern USA: Northern Research Station, U.S. Department of Agriculture Forest Service, Delaware, Ohio, accessed February 2009 at $h t t p: / / w w w . n r s$. fs.fed.us/atlas/tree

Redmond, D.R., 1955, Studies in forest pathology: XV. Rootlets, mycorrhiza, and soil temperature in relation to birch dieback: Canadian Journal of Botany, v. 33, p. 595-627.

Sanders, S., and McGraw, J.B., 2005, Hydrastis canadensis L. (Ranunculaceae) distribution does not reflect response to microclimate gradients across a mesophytic forest cove: Plant Ecology, v. 181, p. 279-288.

Setliff, E.C., 2002, The wound pathogen, Chondrostereum purpureum, its history and incidence on trees in North America: Australian Journal of Botany, v. 50, p. 645-651.

Stebbins, G.L., and Major, J., 1965, Endemism and speciation in the California flora: Ecological Monographs, v. 35, p. $1-35$.

Steuter A.A., and Steinauer, E.M., 1993, Paper birch in the Niobrara Valley of Nebraska: A changing landscape offsets climate change: Natural Areas Journal, v. 13, p. 243-249.

Systat Software, Inc., 2004, Systat for Windows Version 11.00.11, Chicago, Ill.

Terrell, G.R., 1999, Mathematical statistics: A unified introduction: 1st edition, Springer-Verlag, New York, 453 p.

U.S. Department of Agriculture, 1965, Silvics of forest trees of the United States: Forest Service Agricultural Handbook No. 271, 762 p.

U.S. Department of Agriculture, 2005, Protocols for FIA Phase 3 measurements. Crowns: measurement and sampling: accessed November 2008 at http://www.fia.fs.fed. us/library/field-guides-methods-proc/docs/2006/p3_3-0_ sec12_10_2005.pdf

Woodward, F.I., 1987, Climate and plant distribution, Cambridge, Cambridge University Press, 188 p.

Wright, H.E., 1970, Vegetational history of the central plains, in Dort, W., and Jones, J.K., eds., Pleistocene and recent environments of the central Great Plains: Lawrence, University of Kansas Press, p. 157-172.
Zhu, X.B., Cox, R.M., and Arp, P.A., 2000, Effects of xylem cavitation and freezing injury on dieback of yellow birch (Betula Alleghaniensis) in relation to a simulated winter thaw: Tree Physiology, v. 20, p. 541-547. 
Publishing support provided by: Rolla Publishing Service Center

For more information concerning this publication, contact: Director, USGS Columbia Environmental Research Center 4200 New Haven Road

Columbia, MO 65201

(573) 875-5399

Or visit the Columbia Environmental Research Center Web site at: http://www.cerc.usgs.gov/ 



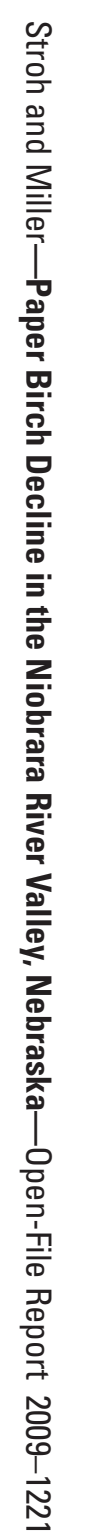

